Nova Southeastern University

Florida

NSUWorks

Faculty Scholarship

Shepard Broad College of Law

Spring 1-1-2013

\title{
Legal Education in Disruption: The Headwinds and Tailwinds of Technology
}

Jon M. Garon

Follow this and additional works at: https://nsuworks.nova.edu/law_facarticles

\section{Recommended Citation}

Jon M. Garon, Legal Education in Disruption: The Headwinds and Tailwinds of Technology, 45 CONN. L. REV. 1165 (2013).

This Article is brought to you for free and open access by the Shepard Broad College of Law at NSUWorks. It has been accepted for inclusion in Faculty Scholarship by an authorized administrator of NSUWorks. For more information, please contact nsuworks@nova.edu. 


\section{CONNECTICUT \\ LAW REVIEW}

VOLUME 45 MAY 2013 NUMBER 4

\section{CONTENTS}

\section{ARTICLES}

Next Phase Pedagogy Reform for the Twenty-First

CENTURY LEGAL EDUCATION: DELIVERING COMPETENT

LAWYERS FOR A CONSUMER-DRIVEN MARKET Ann Marie Cavazos

LEGAL EDUCATION IN DISRUPTION:

THE HEADWINDS AND TAILWINDS OF TECHNOLOGY Jon M. Garon

JUKIN' THE STATS: THE GAMING OF LAW SCHOOL

RANKINGS AND HOW TO STOP IT Darren Bush \& Jessica Peterson

DEMOCRATIZING LEGAL EDUCATION Renee Newman Knake

KIM KARDASHIAN AND HONEY BOO BOO:

MODELS FOR LAW SCHOOL SUCCESS (OR NOT) George Critchlow

\section{ESSAYS}

WHAT'S GOING ON? THE PSYCHOANALYSIS

METAPHOR FOR EDUCATING LAWYER-COUNSELORS ....Jeffrey M. Lipshaw

THE IMPACT OF RANKINGS AND

RULES ON LEGAL EDUCATION REFORM David Yellen

RETHINKING U.S. LEGAL EDUCATION:

NO MORE "SAME OLD, SAME OLD". Nancy B. Rapoport

\section{NOTES}

IDEOLOGICAL EXCLUSION IN THE POST-9/11 ERA:

A CASE FOR INCREASED JUDICIAL OVERSIGHT AND

RECOGNITION OF THE RIGHT TO HEAR SPEECH. Sean D. Acevedo

SeCond Wind: A Legal and Policy-BASEd EVALUATION OF THE BLOCK ISLAND WIND FARM AND THE LEGISLATION THAT SAVED IT Brian M. Gibbons 


\title{
CONNECTICUT \\ LAW REVIEW
}

\begin{tabular}{lll}
\hline \hline VOLUME 45 & MAY 2013 & NUMBER 4 \\
\hline
\end{tabular}

\section{Article}

\section{Legal Education in Disruption: The Headwinds and Tailwinds of Technology}

\author{
JON M. GARON
}

By harnessing improvements in communications and computational systems, law firms are producing a revolution to the practice of law. Selfhelp legal manuals have transformed into interactive software; predictive coding can empower clients to receive sophisticated legal advice from a machine; socially mediated portals select among potential lawyers and assess the quality of the advice given; and virtual law firms threaten to disintermediate the grand edifices of twentieth century Big Law. These changes have profoundly restructured the legal practice for many solo and small firm practices. Successful small firms are adapting the technology to become much more efficient and much less reliant on their geographic location.

This Article focuses on the implications of these profound disruptive changes. It looks at the expectations the market may place on future lawyers and by extension the training necessary for lawyers entering the practice of law. The final section reflects a suggested curriculum and programmatic redesign, highlighting one possible future legal educational model, complete with acquiescence to existing constraints found in American Bar Association and other accreditation regimes. 


\section{ARticle Contents}

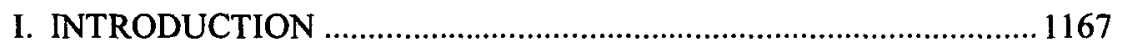

II. REQUIEM FOR THE MYTHICAL LAWYER ............................... 1168

A. The THREAT (TO LAWYERS) OF SELF-HELP ................................... 1174

B. Predictive DRAFTING AND OTHER DisRuPtive INNOVATIONS ........1178

C. THE THREAT OF THE RECONSTITUTED LAW FIRM ..............................1180

III. THE LAWYER UNBOUND:

RISE OF THE NETWORKED LAWYER …................................. 1186

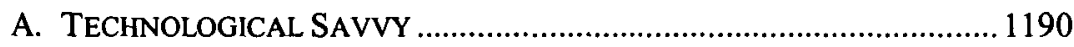

B. EFFICIENT AND ECONOMICAL ...................................................... 1191

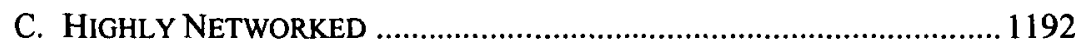

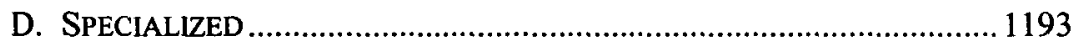

E. UNBUNDLED PURVEYORS OF LIMITED SERVICES ........................... 1194

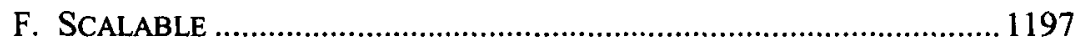

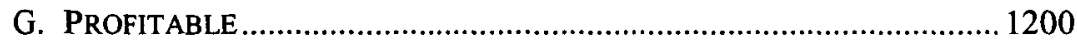

H. SOCIALLY RESPONSIBLE AND CIVICALLY ENGAGED ..................... 1202

I. EXEMPLIFYING WORK-LIFE BALANCE AND CULTURAL SENSITIVITY.................................................... 1203

J. VALUED INTERMEDIARIES PROVIDING HIGHLY PERSONALIZED CONSULTATIVE ADVICE …..................................................... 1205

IV. REINVENTING THE LAW SCHOOL FOR THE INFORMATION AGE ..................................................... 1208

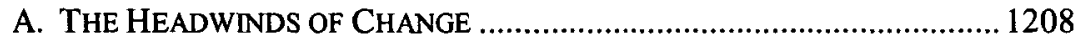

B. RETAINING THE CORE OF THE CURRICULUM .................................. 1214

C. AdDING MEANING To MaCCRATE: Which SkILlS AND Values

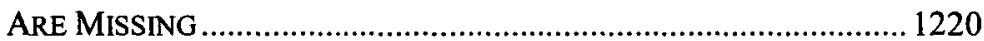

D. RETHINKING HOW TO DELIVER LEGAL EDUCATION ........................ 1226

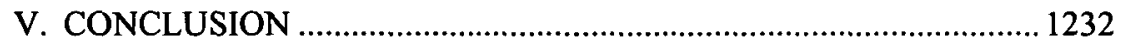

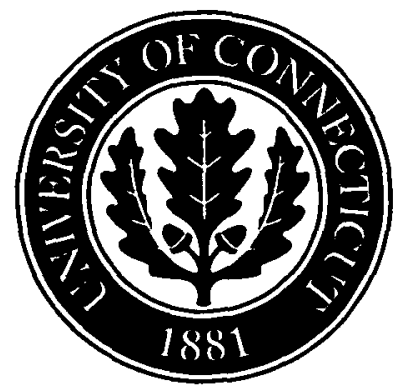




\title{
Legal Education in Disruption: The Headwinds and Tailwinds of Technology
}

\author{
JON M. GARON*
}

[S]pecialized work, mass-production, cheapened production, advertising and selling-finding the customer who does not know he wants it, and making him want it: these are the characteristics of the age. Not, yet, of the Bar. ${ }^{1}$

- Karl N. Llewellyn

Technology is here to stay and ignoring it is no longer an option. . . It's time for the legal profession to pull its collective head out of the sand ....2

- Carolyn Elefant \& Nicole Black

\section{INTRODUCTION}

The practice of law has changed significantly in the last half-century. The majority of work has shifted from individuals to legal entities; the majority of attorneys have moved from solo practices and small firms to increasingly large national and multinational organizations; face-to-face office visits have often been replaced with digital technology through email, cell phones, and web portals; legal services are priced too high for the majority of the public to access lawyers; and the result is that legal service demands have declined precipitously in recent years ${ }^{3}$-a decline that may be significantly steeper than the economic downturn would predict. When the economy rebounds, the additional efficiencies squeezed out of law firms will not go away. Job growth in the legal sector will not

- Director, NKU Chase Law + Informatics Institute and Professor of Law, Salmon P. Chase College of Law, Northern Kentucky University; J.D. Columbia University School of Law 1988. For comments and insight on this or my earlier projects on this topic, I would like to thank Dennis Honabach, Nancy Rapoport, Richard Bales, Jennifer Kreder, Michael Schwartz, Gerald Hess, Sophie Sparrow, and Greg Sergienko.

${ }^{1} \mathrm{~K}$. N. Llewellyn, The Bar's Troubles, and Poultices-and Cures?, 5 LAW \& CONTEMP. PROBS. 104,115 (1938).

${ }^{2}$ Carolyn Elefant \& Nicole Black, Social Media for Lawyers: The NeXt Frontier 187 (2010).

${ }^{3}$ See 2011 Client Advisory, HILdEBRANDT BAKER RobBIns \& CITI PrIVATE BANK 2, available at http://peermonitor.thomsonreuters.com/ThomsonPeer/docs/2011_Client_Advisory_FINAL.pdf (last visited Jan. 28, 2013) ("The growth in demand for legal services has been negative in each of the past seven quarters."). 
rebound quickly.

The natural effect of these changes would be a direct effect on how law schools educate and prepare future lawyers to enter the practice of law. In actuality, however, the changes in legal education are largely experimental or particular to a single law school. Despite calls for law school reform, the actual education of law students has changed very slowly.

This Article focuses on the direct implications of the profound disruptive change ${ }^{4}$ affecting the practice of law. It first develops the case that changes to technology and the legal economy have fundamentally shifted the practice of law away from the underlying assumptions that existed when the modern law school curriculum was put in place. It then highlights the attributes necessary for maintaining a successful practice in the future. Finally, the Article suggests that there are necessary changes to law school curricula and programming essential for law school graduates in the modern profession of law. These suggested approaches are made in the context of the existing constraints found in the American Bar Association and other accreditation regimes. ${ }^{5}$

A great deal of evidence is likely required to convince members of the legal academy that profound disruptive change is occurring and that the time has come to step into the new curriculum before good law schools face redundancy, disintermediation, and closure. The outlines for the future of legal education are only suggestions. The Article hopes to further the ongoing dialogue among members of the legal, educational, and professional communities to identify which particular skills, attributes, and values will be needed by a lawyer over the next half-century in order to implement change more broadly and quickly.

\section{REQUIEM FOR THE MYTHICAL LAWYER}

Harper Lee penned a superhero in Atticus Finch, a poor country lawyer who educated his children, crossed racial barriers, and met his clients where he found them. ${ }^{6}$ He accepted stove wood and hickory nuts as payment from a farmer devastated by the Dustbowl and Great Depression. ${ }^{7}$

${ }^{4}$ This Article builds on a more general article regarding industries facing disruptive change. See Jon M. Garon, Mortgaging the Meme: Financing and Managing Disruptive Innovation, 10 Nw. J. TECH. \& INTELL. PROP. 441, 479-81 (2012) [hereinafter Garon, Mortgaging the Meme] (identifying how profound disruptive change requires innovative management strategy and hard self-appraisals of markets).

${ }^{5}$ It is axiomatic that responses to disnuptive innovation that fail to recognize existing boundary conditions and external constraints are relegated to curiosities rather than manifestos. While a good plan can identify which constraints should be prioritized for change, successful planning requires that internal changes begin before the external barriers are overcome.

${ }^{6}$ See generally HARPER LeE, TO KILl A MOCKINGBIRD (Harper Collins 40th Anniversary ed. 1999) (1960).

${ }^{7}$ Id. at 22-23. 
He undertook to represent unpopular cases because every person was entitled to competent representation. And he strove to make his community uphold the ideals of a blind and equal justice, despite the prejudice and self-interest of those around him. ${ }^{8}$

Atticus Finch embodied the values of the legal profession-as captured through a rose-colored history ${ }^{9}$ and the professional ethics being developed during the same era in which the novel is set. ${ }^{10}$ But lawyers did not set out to be poor. ${ }^{11}$ They worked hard to compete with one another, to become successful, ${ }^{12}$ and to keep the competition from undermining the monopoly

${ }^{8} I d$. at 234. Atticus recognized:

Our courts have their faults, as does any human institution, but in this country our courts are the great levelers, and in our courts all men are created equal.

I'm no idealist to believe firmly in the integrity of our courts and in the jury system - that is no ideal to me, it is a living, working reality. Gentlemen, a court is no better than each man of you sitting before me on this jury. A court is only as sound as its jury, and a jury is only as sound as the men who make it up.

Id.

${ }^{9}$ See Thomas D. Morgan, The Vanishing American LawYer 24-25 (2010) (stating that the conception of lawyers as a professional group in the post-Civil War era and after World War II was not an accurate reflection of reality).

${ }^{10}$ See Robert MacCrate, "The Lost Lawyer" Regained: The Abiding Values of the Legal Profession, 100 DICK. L. REV. 587, 591-94 (1996) (discussing the emergence and development of professional standards of conduct and values for lawyers, including the importance of representing the indigent).

$"$ See, e.g., Robert W. Gordon, The American Legal Profession, 1870-2000, in 3 THE Cambridge History OF LAW IN AMERICA, THE TWentieth CENTURy and AFter 73, 75-78 (Michael Grossberg \& Christopher Tomlins eds., 2008) (discussing how the legal profession was stratified with elite lawyers who sought to limit access to the profession at the top).

${ }^{12}$ See 1 AleXIS DE TOCQUEVILle, DEMOCRACY IN AMERICA 262-64 (Henry Reeve trans., Arlington House 1966) (1831) (discussing the role that lawyers play in tempering the "excesses of democracy").

\begin{abstract}
In visiting the Americans and in studying their laws, we perceive that the authority they have entrusted to members of the legal profession, and the influence which these individuals exercise in the Government, is the most powerful existing security against the excesses of democracy. ... Men who have more especially devoted themselves to legal pursuits, derive from those occupations certain habits of order, a taste for formalities, and a kind of instinctive regard for the regular connection of ideas, which naturally render them very hostile to the revolutionary spirit and the unreflecting passions of the multitude. ... But it must then be inquired whether the cause which induces them to innovate and destroy is accidental, or whether it belongs to some lasting purpose which they entertain. It is true that lawyers mainly contributed to the overthrow of the French Monarchy in 1789; but it remains to be seen whether they acted thus because they had studied the laws, or because they were prohibited from co-operating in the work of legislation.
\end{abstract}

Id.; see also Phil C. Neal, DeTocqueville and the Role of the Lawyer in Society, 50 MARQ. L. REV. 607, 610-15 (1967) (discussing different aspects of the lawyer's role, including the instrumental, the protective, the sphere of conflict, and civic wisdom) 
over the practice of law. ${ }^{13}$ For much of the last century, the legal profession succeeded. Prior to the 2009 economic downturn, the legal profession was growing. ${ }^{14}$ But despite this, "the demand from poor persons unable to pay for needed legal services exceeds the supply. There continues to be a serious shortage in the number of legal service providers available to serve the poor." 15 Whatever romantic notions might have resonated around Atticus Finch, neither the myth of the country lawyer nor the myth of the pro bono lawyer reflect the market into which law students graduate.

Technology is neutral; it does not impinge the values of Atticus Finch. But in making legal services more readily available to our nation's poor and middle class, technology may disintermediate the local lawyer, eliminating many of the interactions between lawyer and client and driving community lawyers out of business. As Dean Thomas Morgan has opined, "even the term 'lawyer' itself will increasingly be seen as imprecise and obsolete. . . . For better or worse, most of tomorrow's lawyers will resemble what we today call business consultants more than they will call to mind Clarence Darrow and Atticus Finch."16

While the transformation from the workingman's lawyer to the business consultant is less significant for lawyers who are agnostic regarding the nature of their practice and motivated primarily to engage in a successful career, it does implicate both the access to legal services for the individual and the nature of the legal education designed to prepare lawyers.

\footnotetext{
${ }^{13}$ Gordon, supra note 11 , at $84-85$.
}

Skeptics about professions claim that they are primarily economic cartels, designed to create and protect a guild monopoly. The organized bar of the twentieth century certainly did its share to prove those skeptics right. State bars put in place an impressive array of arrangements that restricted competition among lawyers and between lawyers and other professions. Proponents invariably argued that such arrangements, like statutes forbidding the "practice of law" by corporations or rules forbidding lawyers to advertise their services or solicit clients, were needed to preserve law as a high-minded profession against commercial money-grubbers who would turn it into a mere business. Starting in the 1920s, "unauthorized practice of law" committees fought fierce turf battles with encroaching neighbors-accountants giving tax advice, "administrative" specialists handling cases before agencies, collection agencies, trust companies writing wills and administering trusts, title insurers and real estate brokers handling property sale closings, unions and automobile clubs offering group legal services, and most recently paralegals offering help in preparing legal documents.

Id. at 84 .

${ }^{14}$ See Quintin Johnstone, An Overview of the Legal Profession in the United States, How That Profession Recently Has Been Changing, and Its Future Prospects, 26 QUINNIPIAC L. REV. 737, 738 (2008) (noting that demand for legal services was increasing).

${ }^{15}$ Id. at 739.

${ }^{16}$ MORGAN, supra note 9, at 25. 
In a well-regarded study by John Heinz and Edward Laumann, the authors noted that lawyers representing individuals had dropped to $29 \%$ of attorneys-down from $40 \%$ twenty years earlier. ${ }^{17}$ Instead, $64 \%$ of lawyers moved into corporate practice, up from $53 \%$ in the same period. ${ }^{18}$ An additional $10 \%$ of lawyers served as in-house counsel. ${ }^{19}$

For the $29 \%$ of attorneys continuing to represent individuals, the economics have also become somewhat daunting. A 2007 news report by the Wall Street Journal (the first of many), reported IRS data that "the inflation-adjusted average income of sole practitioners has been flat since the mid-1980s." ${ }^{, 20}$ The report added "[a] recent survey showed that out of nearly 600 lawyers at firms of 10 lawyers or fewer in Indiana, wages for the majority only kept pace with inflation or dropped in real terms over the past five years." 21

"The economic downturn being experienced in the United States in virtually every area of activity is not a simple cycle but a transformation. This non-linear shift in competitive conditions demands changes in behavior, institutional structures and assumptions in many areas, including education." ${ }^{22}$ Although much has been written regarding the rise and transformation of Big Law, ${ }^{23}$ little has been said about the decline of the Atticus Finch ideals embodied in small and solo practice. Technology-or the "information substructure"--may well be the next great threat to the

${ }^{17}$ John P. Heinz et al., The Scale of Justice: Observations on the Transformation of Urban Law Practice, 27 ANN. REV. Soc. 337, 340 (2001); see also MORGAN, supra note 9, at 110-11 (noting a decrease in the percentage of lawyers that represent individuals).

${ }^{18}$ Heinz et al., supra note 17, at 339-40.

19 Susan Hackett, Inside Out: An Examination of Demographic Trends in the In-House Profession, 44 ARIZ. L. REV. 609, 610 \& n.5 (2002) (comparing data with ClARA N. CARSON, THE LAWYER STATISTICAL REPORT: THE U.S. LEGAL PROFESSION IN 1995, at 1 (1999)); see also Johnstone, supra note 14, at 766 ("The total number of U.S. lawyers that are house counsel has increased greatly in recent years.").

${ }^{20}$ Amir Efrati, Hard Case: Job Market Wants for U.S. Lawyers, WALL ST. J., Sept. 24, 2007, at Al.

${ }^{21} I$ d.

${ }^{22}$ David Barnhizer, Redesigning the American Law School, 2010 MICH. ST. L. REV. 249, 250 (2010).

${ }^{23}$ See, e.g., Bernard A. Burk \& David McGowan, Big but Brittle: Economic Perspectives on the Future of the Law Firm in the New Economy, 2011 COLUM. BUS. L. REV. 1, 5 (2011) (characterizing the bar's reaction to the decline of Big Law as "hover[ing] uncomfortably between turmoil and denial"); Larry E. Ribstein, The Death of Big Law, 2010 WIS. L. REV. 749, 751-52 (2010) (asserting that Big Law is not suffering from a short-term decline in the economy or from a decreased demand for legal services, but from long-term problems, in particular "the non-viability of its particular model of delivering legal services"); Cassandra Burke Robertson, A Collaborative Model of Ofjshore Legal Outsourcing, 43 ARIZ. ST. L.J. 125, 132 (2011) (highlighting the growth of legal off-shoring and concluding that " $[\mathrm{t}] \mathrm{he}$ percentage of work involving high-level outsourcing is likely to continue to grow"); Carole Silver, What We Don't Know Can Hurt Us: The Need for Empirical Research in Regulating Lawyers and Legal Services in a Global Economy, 43 AKRON L. REV. 1009, 1023-24 (2010) (asserting the increasing importance of an appropriate regulatory framework as United States lawyers and law firms look overseas for opportunities as they embrace a strategy of globalization). 
profession, disrupting the existing business models in ways that will reduce the number of solo and small firm practitioners even as it restructures the activities taking place within Big Law. ${ }^{24}$

For the medium-sized firms, "the biggest change in the practice of law at their firms has been the use of technology in client service, firm management, and to a lesser extent marketing."25 For medium-sized firms, technology has provided them with competitive leverage to stay competitive. "[T]echnology has been the most significant change in the last ten years. [Medium-sized firms] have significantly invested in technology and training, and they believe this investment has enhanced their ability to compete with larger firms for clients." ${ }^{26}$ Medium-sized firms have also taken advantage of contract attorneys and legal services outsourcing (using Indian and other off-shore attorneys) to provide lower cost, efficient, and highly scalable services to clients and compete with Big Law on cost and efficiency. ${ }^{27}$

The solo and small practice bar is not as well positioned. It sees the technological changes as a "headwind" challenging the value of the practice of law to their clients:

We face headwinds of technology. Technology, you would think, is purely a tailwind for our profession, as it has helped us reach unprecedented levels of efficiency.... [M]any of us may feel that technology has become a headwind pushing us backward and bringing practices to a screeching halt. Just ask a general practice lawyer about new clients who arrive loaded with stacks of free legal information found online. Your time and advice? They don't want it ... or much of it. Even on a legal matter of significant proportions, they seek

${ }^{24}$ See RICHARD SUSSKIND, THE END OF LAWYERS? 17 (2008) (using “information substructure" to refer to "the dominant means by which information is captured, shared, and disseminated within society").

${ }^{25}$ Ward B. Coe III, Profound "Nonchanges" in Small and Midsize Firms, 70 MD. L. REV. 364, $368(2011)$

${ }^{26} \mathrm{Id}$.

${ }^{27}$ See Carlo D'Angelo, Overseas Legal Outsourcing and the American Legal Profession: Friend or "Flattener"?, 14 TEX. WESLEYAN L. REV. 167, 168 (2008) (noting the phenomenon of white-collar jobs moving abroad at record numbers to English-speaking countries like India, where they are performed at a fraction of the cost); Lee A. Patterson III, Outsourcing of Legal Services: A Brief Survey of the Practice and the Minimal Impact of Protectionist Legislation, 7 RICH. J. GLOBAL L. \& BUS. 177, 179 (2008) ("[O]utsourcing often increases efficiency, as offshore workers are eager to perform well in jobs that lack prestige and good pay in the United States, thus increasing profits for American firms that utilize these workers."); Robertson, supra note 23, at 134 ("Indian revenue from legal process outsourcing (LPO) was valued at $\$ 320$ million in 2008 , and expected to grow to $\$ 640$ million by 2015."); Mark L. Tuft, Supervising Offshore Outsourcing of Legal Services in a Global Environment: Re-Examining Current Ethical Standards, 43 AKRON L. REV. 825, 827-28 (2010) (describing "offshoring" as one form of legal outsourcing, "in which a firm relocates certain legal and law-related services to a foreign jurisdiction that allows the firm to realize greater efficiency and lower costs"). 
only an hour or two of your time so they can finish the work themselves. $^{28}$

The bar associations see the decline in client patience for expertise and attention. Increasingly, clients want a lawyer only to check their own work - and even that represents a fraction of those who even bother to do so. This is not what the country lawyer signed up for. ${ }^{29}$ Nonetheless, solo and small firm practitioners represent the core of the legal profession:

Of American lawyers in private practice, about 70 percent work in solo offices or law firms with 20 or fewer members. It is estimated that the United States has about 435,000 solo law practitioners (comprising about 48 percent of privatepractice lawyers) and about 200,000 lawyers in firms of between two and 20 lawyers (about 22 percent of lawyers in private practice) ${ }^{30}$

Whether the solo practitioners are in urban, suburban, or rural areas, many of their challenges remain the same. Technology-particularly in the form of ubiquitous content from self-help software-has devalued the importance of the information they provide, put tremendous pressure on the fees they can charge for such information, and undermined locale as a distinguishing factor in one's practice. These solo practitioners and small firm lawyers are not, of course, necessarily lawyers representing individual clients. The majority are corporate lawyers operating from smaller organizations and presumably representing the small to medium sized enterprises that could not afford legal representation by Big Law.

Richard Susskind described the process as the commoditization of the legal profession. ${ }^{31} \mathrm{He}$ distinguishes between "bespoke" work"traditional, hand-crafted, one-to-one consultative professional service highly tailored for the specific needs of particular clients"-and legal work that can be packaged and commoditized. "In short, bespoke service is highly customized service." ${ }^{33}$ Susskind points out that "when legal tasks

${ }^{28}$ Julie I. Fershtman, Looking Inward, Listening, and Providing Service in Challenging Times, MICH. B.J., Oct. 2011, at 16, 16-17.

${ }^{29}$ See Buck Lewis, A Salute to 'Short-Building' Lawyers, TENN. B.J., Mar. 2009, at 3, 3 ("[C]ountry lawyers call city lawyers like me, 'tall building lawyers,' meaning of course, that we practice law in tall buildings and implying, quite accurately, that we tall-building lawyers have gaps the size of Humvees in our understanding of the everyday life of small-town lawyers.").

${ }^{30}$ Press Release, Am. Bar Ass'n, ABA Serves Solo and Small-Firm Lawyers with New Online Resource Center (Jan. 19, 2012), available at http://www.abanow.org/2012/01/aba-serves-solo-andsmall-firm-lawyers-with-new-online-resource-center/.

${ }^{31}$ SUSSKIND, supra note 24 , at 27-35.

${ }^{32}$ Id. at 29 ("In the UK, we speak of bespoke software when we mean software that is specially written for one client or customer. We also talk about bespoke tailoring-a bespoke suit, of a Savile Row variety for example, is tailored for one individual.").

${ }^{33} \mathrm{Id}$. 
are recurrent . . . there is the tendency for lawyers . . to 'standardize.",34 He uses "systematized" to refer to the internal mechanics of workflow that can also be automated, such as software-based document assembly and electronic checklists. ${ }^{35}$ When the systematized products can be offered directly to clients, the resulting product, or software service, Susskind applies the label "packaged." 36

For Susskind, the step from package to commodity is a specific one:

[A] commoditized legal service is an IT-based offering that is undifferentiated in the marketplace (undifferentiated in the minds of the recipients and not the providers of the service). For any given commodity, there may be very similar competitor products, or the product is so commonplace that it is distributed at low or no cost. ${ }^{37}$

Susskind is correct to distinguish between commodities and packaged products. But for the practitioner who does not sell one of the packages, the distinction may not be meaningful. Both packaged and commoditized low-cost alternatives cut directly into the attorneys' profits and reduce opportunities to engage the client. The bespoke services of a trusted counselor often grow as the relationship and trust between attorney and client mature through successful interactions. Without the low-cost, lowrisk systematized work, a lawyer may find it difficult to attract clients interested in bespoke work.

\section{A. The Threat (to Lawyers) of Self-Help}

The first threat to the solo and small firm practitioner is the rise of selfhelp legal services. The distinction between the packaging of legal services by attorneys and the distribution of legal services as a commodity sold by publishers can be seen in the marketplace separating Nolo Press and LegalZoom from the vast array of law office websites promoting free or low-cost services. ${ }^{38}$ Companies such as Nolo Press and LegalZoom have been growing dramatically, ${ }^{39}$ providing consumers sophisticated and

${ }^{34} I d$.

${ }^{35}$ Id. at 30.

${ }^{36}$ Id. at 31 ; see discussion of Nolo Press, infra at Part II.A.

${ }^{37}$ SUSSKIND, supra note 24 , at 32.

${ }^{38}$ A Google search conducted on January 30,2013 , for the phrase "free will" returned 16,600,000 results.

${ }^{39}$ See Rejoinder: "Is the Virtual Law Model Coming Up Short?", PRO-SEBLOG.COM, http://proseblog.com/2011/09/24/rejoinder-is-the-virtual-law-model-coming-up-short/ (last visited Feb. 25, 2013) (" $[W]$ e see the emergence of companies like LegalZoom . . . [and] Nolo, and the dozens of other non-lawyer intemet-based legal solution providers who are responding to the need of consumers for a 'good enough' legal result at the lowest possible cost. ... [These consumers] do the best they can with a legal solution provided by a non-lawyer provider ...."). 
complete legal products so that the consumer has little or no need of a lawyer.

The first of these companies was Nolo Press, started in the 1970s as part of the self-help counterculture. ${ }^{40}$ It set the standard for self-help legal publications and forms. It successfully fought off charges of practicing without a license, developing a strong audience as well as competitors such as Quicken and Kiplinger. "11 "But [founder and President Ralph "Jake"] Warner thinks Nolo knows its audience best. It is 'the National Public Radio crowd' he says. 'These are people who find it reasonable to read up on law for a couple of hours and then only buy the legal services they need." 42 Nolo Press retooled in the information age to become Nolo.com and continues to be one of the leading self-help resources in legal publishing.

Nolo now publishes the Quicken legal products. ${ }^{43}$ But some state bar associations have pressed back against the self-help materials. In Texas, the Unauthorized Practice of Law Committee brought suit against Parsons Technology, Inc. for its software products "Quicken Family Lawyer, version 8.0," and "Quicken Family Lawyer "99."44 The committee alleged that Quicken Family Lawyer conducted itself "as a "high tech lawyer by interacting with its "client" while preparing legal instruments, giving legal advice, and suggesting legal instruments that should be employed by the user.' In other words, [Quicken] is a 'cyber-lawyer." "45 The district court upheld this view and enjoined the sale of the products. ${ }^{46}$

Despite the victory for the Texas State Bar, the success was shortlived. The Texas legislature amended the practice of law statute while the case was on appeal to clarify that the citizens of Texas wanted inexpensive legal software to be available in that state. The legislature added a limitation to the statutory definition of lawyer:

[T] he "practice of law" does not include the design, creation, publication, distribution, display, or sale, including publication, distribution, display, or sale by means of an Internet web site, of written materials, books, forms, computer software, or similar products if the products clearly

${ }^{40}$ Stephanie B. Goldberg \& Gary Poole, Success at Nolo Press: A Berkeley Upstart of the '70s Becomes the Guru of Legal Self-Help, BUS. WEEK'S FRONTIER (Jan. 31, 2000), http://www.businessweek.com/smallbiz/0002/la3666045.htm.

${ }^{41} I d$.

${ }^{42} I d$.

${ }^{43}$ See Quicken Legal Business Pro 2012, AMAZON.COM, http://www.amazon.com/QuickenLegal-Business-Pro-2012/dp/B00SCELLZM/ (last visited Jan. 30, 2013) (selling the Nolo software).

${ }^{44}$ Unauthorized Practice of Law Comm. v. Parsons Tech., Inc., No. 3:97-CV-2859-H, 1999 U.S. Dist. LEXIS 813, at *2-3 (N.D. Tex. Jan. 22, 1999), vacated, 179 F.3d 956 (5th Cir. 1999).

${ }^{45} I d$. at *13-14 (citation omitted).

${ }^{46}$ Id. at $* 36$. 
and conspicuously state that the products are not a substitute for the advice of an attorney. ${ }^{47}$

With the state legislature superseding the self-regulation regarding the practice of law, the district court decision was reversed. ${ }^{48}$ The lesson was clear-lawyer self-regulation remains a courtesy provided by state and federal legislatures, which they will revoke if the practicing bar overreaches with its monopoly.

The legislative triumph over the Texas Bar Association paved the way for more computer products and more publishers. Today competitors abound, with LawDepot.com, BizTree.com, and others fighting for these revenues for document construction. ${ }^{49}$ LegalZoom is perhaps the most visible in the current marketplace. ${ }^{50}$ LegalZoom, for example, "charges $\$ 69$ for wills and as little as $\$ 99$ for articles of incorporation, versus the thousands that a lawyer might charge for the same product." ${ }^{\text {51 }}$ Profitable from its inception, it uses the new rounds of funding to improve its software, increase its ability to provide the correct documents, and remain up-to-date in the various jurisdictions. ${ }^{52}$ Not to be outdone, Standard Legal charges $\$ 14.95$ to $\$ 34.95$ for its "Legal Forms Software" and uses the high cost of LegalZoom to promote its products. ${ }^{53}$ Other incorporation services also highlight that their prices are substantially below the LegalZoom cost. $^{54}$

LegalZoom does not take business away from Big Law, but instead takes a portion of the more lucrative practice away from the solo and small firm practitioners, squeezing their profitability and reducing their non-

${ }^{47}$ TEX. GOV'T CODE ANN. § 81.101(c) (West 2005).

${ }^{48}$ Unauthorized Practice of Law Comm. v. Parsons Tech., Inc., 179 F.3d 956, 956 (5th Cir. 1999).

${ }^{49}$ See BizTrEe, http://www.biztree.com/ (last visited Feb. 25, 2013) (advertising itself as "The World's \#1 Business Document Templates Software"); LAwDEPOT, http://www.lawdepot.com/ (last visited Feb. 25, 2013) (offering customers the opportunity to "[c]reate customized legal documents in minutes").

${ }^{50}$ See Daniel Fisher, Silicon Valley Sees Gold in Internet Legal Services, ForBes (Oct. 5, 2011), $\mathrm{http}: / / \mathrm{www}$.forbes.com/sites/danielfisher/2011/10/05/silicon-valley-sees-gold-in-internet-legalservices/ ("LegalZoom has raised $\$ 100$ million from such shops as Kleiner Perkins and Institutional Venture Partners, which invested $\$ 41$ million earlier this year. Google Ventures recently joined an $\$ 18.5$ million financing of a LegalZoom competitor, Rocket Lawyer, and Internet Brands bought Nolo, an online provider of legal forms and education. These startups match a lot of [Venture Capital] checklists: disruptive models in huge, decentralized businesses.").

${ }^{51} I d$.

${ }^{52}$ Id. ("Using flashy television and Internet advertising, LegalZoom claims 1 million customers and revenue of more than $\$ 100$ million this year.").

${ }^{53}$ Are You Getting "Zoomed"?, STANDARD LEGAL, http://www.standardlegal.com/legalzoom.ht $\mathrm{ml}$ (last visited Jan. 30, 2013).

${ }^{54}$ See, e.g., Competition Price Comparison (Legalzoom, etc.), CORPS. FLORIDA, http://www.florida-incorporation.com/price-comparison-legalzoom-vs-us.html (last visited Jan. 30, 2013) (advertising that LegalZoom charges $\$ 369$ plus state fees and takes up to ten days for "simple" incorporation services that they process in the same business day and provide "[f]or free"). 
litigation clientele.

A more interesting-but potentially just as disruptive-publisher in the market is FindLaw. ${ }^{55}$ Owned by Thomson/Reuters, parent to Westlaw, the company republishes legal forms supplied by LegalZoom and promotes a host of other services. ${ }^{56}$ FindLaw also dwarfs the new entrants in the market, "[w]ith more than 1000 employees and over $\$ 100$ million in annual revenue." $" 57$

FindLaw fits into a fascinating space in the legal information ecosystem. It offers free content to consumers, helps promote attorneys, derives advertising revenue from site usage, and makes it extremely difficult for any new entrant to challenge the premium publishing services of Westlaw or Lexis. Cornell University's free website does much of the same thing ${ }^{58}$ and together they provide free access to U.S. law. FindLaw could certainly grow to dominate the mediated legal landscape. As its services expand, the primary audience may well be the consumers that would previously have turned to solo and small office practitioners for assistance.

Self-help is also a double-edged sword. Like cookbooks in a commercial kitchen, these tools are often the hidden arsenal of the new solo attorney, in keeping one step ahead of the client. A recent law school graduate with a newly hung shingle can log onto Nolo or LegalZoom to acquire a wealth of knowledge and training without a mentor or support system. As a result, lawyers of the future need to be trained in how to review these documents critically, so they can make good choices on behalf of their clients.

If the attorney takes time to carefully explain the meaning of the documents, adapt the documents to the particular needs of the client, and remain available to answer questions as the matter matures, then that attorney provides a useful service worthy of compensation. If instead the attorney charges a significant mark-up to do nothing more than fill in blanks, then the consumer has not received any value from that attomey and should not pay more than a secretarial fee.

\footnotetext{
${ }^{55}$ FINDLAw, http://www. findlaw.com/ (last visited Jan. 31, 2013).

${ }^{56}$ FindLaw Legal Forms, FINDLAw, http://forms.findlaw.com/ (last visited Jan. 31, 2013) ("FindLaw, the most popular source of legal information has partnered with U.S. Legal Forms the nation's number one online legal document service. This partnership allows the FindLaw community the ability to research legal topics and act upon on their own legal needs with reliable document preparation services. U.S. Legal Forms offers consumers and small business owners an easy and convenient way to create a last will or living will, form a corporation or LLC, register a trademark and more-online, and without the cost of an attomey.").

${ }^{57}$ FindLaw Corporate Information: Company Background, FindLAw, http://company.findlaw.co $\mathrm{m}$ /company-history/findlaw-corporate-information-press-company-background.html (last visited Jan. 31, 2013).

${ }^{58}$ Legal Information Institute, CORNELL UNIV. L. SCH., http://www.law.cornell.edu/ (last visited Jan. 31, 2013).
} 


\section{B. Predictive Drafting and Other Disruptive Innovations}

Commoditization of legal services is only one of the pressures diminishing law, lawyering, and the legal profession. A second factor is the cultural shift away from mediated information. Disintermediation occurs "where changes in the current business model or advances in technology mean that a company ceases to need to use intermediaries to create the value sought by end customers." ${ }^{.59}$ The value chain for information was disrupted with the advent of the Internet-connected personal computer. Mobile technologies and ubiquitous network connections only accelerate the process.

We are in the midst of a fundamental shift in the economics of information-a shift that "will precipitate changes in the structure of entire industries and in the ways companies compete." ${ }^{1,60}$ This shift is made possible by the widespread adoption of Internet technologies, but it is less about technology than about the fact that a new behavior is reaching critical mass. ${ }^{61}$ Millions of people are communicating at home and at work in an explosion of connectivity that threatens to undermine the established value chains for businesses in many sectors of the economy. ${ }^{62}$

Although the primary tool of the lawyer is information, lawyers were somehow insulated from these changes because the legal information had to be interpreted by a professional that was licensed in the appropriate jurisdiction, recognized in one's field, and familiar with the unique context in which the legal information would be deployed.

In actuality, law is not terribly different from any other business. The knowledge of field and context is little different from other industries' customer relationships. "When managers talk about the value of customer relationships, for example, what they really mean is the proprietary information that they have about their customers and that their customers have about the company and its products." ${ }^{.63}$ The only attribute not similar to brand management is the need for a jurisdictional license.

As the algorithms for the information continue to improve, the need for a lawyer to mediate the information will diminish. For example, the tying of social media responses to legal documents can place a potential user of a form in contact with others who have utilized that precise document.

59 ADRIAN PAYNe, HANDBOOK OF CRM: ACHIEVING EXCELLENCE THROUGH CUSTOMER MANAGEMENT 173 (2005).

${ }^{60}$ Philip B. Evans \& Thomas S. Wurster, Strategy and the New Economics of Information, HARV. Bus. REv., Sept.-Oct. 1997, at 71, 71.

${ }^{61} I d$.

${ }^{62}$ Id. at 74.

${ }^{63}$ Id. at 72 . 
Massive databases of information ${ }^{64}$ allow search algorithms to associate particular client profiles with various types of legal clauses in wills, home purchase agreements, sales contracts, divorce settlements, and other documents. The algorithms will drive increasingly smart drafting choices. While these may not be error free, they may well be prone to no more errors than the ones committed by the local attorney or the Big Law partner.

Other models will focus on socially curated legal forms. Services such as Docracy ${ }^{65}$ are beginning to provide documents created using Creative Commons licenses or offered in the public domain. Users also comment and assist with these documents to help make the use most relevant to the particular needs of the person using the license. ${ }^{66}$ LawPivot has a very similar approach, though it charges fees. ${ }^{67}$ These services are not particularly mature at the moment, but the improvements in search, the expansion of content, and the ability of people to upload their own documents (even if authored by law firms) in exchange for access to other documents will only grow with time.

Disruptive innovation does not necessarily mean the death of the old and the birth of the new; it often means transformation. ${ }^{68}$ But disruptive innovation flows from the non-sustaining improvements that catch incumbents unaware, blindsiding the incumbent when the upstarts with a lower-quality product or service surpass the once-dominant player. ${ }^{69}$

As the software grows in potential, consumers will likely rely on it

${ }^{64}$ Sometimes referred to as "Big Data" or "Cloud Computing." See Bob Violino, Managing Big Data in the Cloud, BASELINE (Feb. 21, 2013), http://www.baselinemag.com/cloudcomputing/managing-big-data-in-the-cloud/ (explaining how enterprises are utilizing the big data and cloud computing trends to handle vastly increasing volumes of information).

${ }^{65}$ DOCRACY, http://www.docracy.com/ (last visited Jan. 30, 2013).

${ }^{66}$ F.A.Q.: About Us, DOCRACY, https://www.docracy.com/application/learnmore (last visited Jan. 30, 2013) ("Docracy is a home for contracts and other legal documents, socially curated by the communities that use them. Our mission is to make these documents freely available for everyone, while in the process making them easier to customize and use. No more shady templates behind a paywall where you click download and just hope for the best. Instead we offer reputable, transparent sources and social proof to help you find something as close as possible to the perfect document.").

${ }^{67}$ Ryan Singel, LawPivot Seeks to Kill (Well, Slash) Startup Lawyer Fees, WIRED.COM (Mar. 25, 2011, 6:46 PM), http://www.wired.com/business/2011/03/lawpivot/.

${ }^{68}$ Clayton M. Christensen, The INNOVATOR'S DilemMa: When NeW TEChNOlogies Cause GREAT FIRMS TO FALL, at xv (1997); Garon, Mortgaging the Meme, supra note 4, at 442; see also Christian Sandström et al., Exploring Factors Influencing Incumbents' Response to Disruptive Innovation, 18 CREATIVITY \& INNOVATION MGMT. 8, 9 (2009) (exploring how established firms react to disruptive innovation in the form of new entrants who initially pose a disnuptive threat and eventually displace old technology).

${ }^{69}$ Sandström et al., supra note 68 , at 9 ("Sustaining technologies have in common that they improve the performance of established products along the dimensions that mainstream customers demand. Disruptive technologies, on the other hand, initially underperform along these dimensions. The lower traditional performance and the ancillary performance attributes create a large market uncertainty around the disruptive innovation."). 
more frequently-further improving the quality of the software. The cycle generates a positive feedback loop. This will change both the source of the advice and the manner in which it is delivered. If the information is mediated by a software interface (and available 24/7), clients will be trained to use software interfaces rather than waiting to meet with human attorneys. Just as the public today prefers ATMs and, increasingly, online services to execute bank transactions, ${ }^{70}$ the legal clients of the future will come to expect the efficiencies and responsiveness of software over their less reliable human counterparts.

The use of software for some legal services will increase expectations for rapid turnaround on all other legal work. For most writers, speed is the enemy of clarity and destroyer of prose. As expectations for turnaround times become more demanding, the pressure will increase and the quality may suffer, encouraging more clients to try software-mediated solutions. "The continued push toward the delivery of legal services online affects the legal profession across the board, from solos to large law firms, and affects ... clients' expectations. ${ }^{, 71}$

Software-augmented legal drafting will also benefit more sophisticated transactions. Where appropriate, software will enhance rather than replace bespoke work, providing effective checklists and quality-controlled provisions in transactions requiring careful analysis and strategic assistance. A lawyer who can effectively provide a contextualized solution, which takes into account the client's long-term goals and objectives, brings the greatest value to the client. As discussed below, developing a curriculum to enable students to learn how to become valuable, "bespoken" resources for their clients will be the key to overcoming the disintermediation triggered by ever-improving software.

\section{The Threat of the Reconstituted Law Firm}

In anticipation of the packaging of legal services, some legal organizations have begun to operate differently. These firms have not yet changed the means of legal service production, but they have recognized that the law firm structure is inherently inefficient and have begun to exploit that inefficiency.

The new models utilize a different organizational structure that relies on process innovations to reduce the overhead costs for the lawyer, share

70 Jim Muench, Bankers Say Tellers Aren't Obsolete, COLUM. BUS. TIMES (June 24, 2011), http://columbiabusinesstimes.com/12053/2011/06/24/bankers-say-tellers-arent-obsolete/ ("Many Callaway Bank branches have senior tellers who are cross-trained to be able to open accounts like customer service representatives, Meyerpeter said, and branches that employed five tellers seven years ago now have only three. So, although there may be fewer tellers, they won't disappear completely.").

7 Stephanie L. Kimbro, Virtual Law Practice: How to Deliver Legal SeRvices ONLINE $1(2010)$. 
marketing costs, and maximize efficiencies. Process innovations focus on the method of doing business to improve efficiency and profitability while decreasing cost. ${ }^{72}$ Process innovation is one of the key areas where successful companies outperform their rivals. Even traditional lawyers "can no longer turn a blind eye to this change if they wish to remain competitive." "B3 "By getting executives focused on what are the systems that are locking out value, we can tear them down and destroy them. The really big challenge is not just in having these ideas, but executing these ideas." $" 14$

\section{The Virtual Law Firm}

One type of firm engaged in this process innovation is the virtual law firm. Instead of offices, the virtual law firm uses a common web portal. ${ }^{75}$ These firms may also have physical offices, but often they do not. To save costs, virtual law offices have eliminated prime real estate and marble entranceways; firm-sponsored charitable foundations and local social engagements; expensive junior associates and summer training programs; and mailroom clerks, typing pools and non-billable secretarial support. ${ }^{76}$ Some of these attributes may have been self-indulgent luxuries, while others were used for marketing or contributed back to the profession. Whatever the categorization, the virtual law firm has opted out.

Moreover, by using the common website portal to standardize communications and employing attorneys in each jurisdiction, a law firm can provide the information services nationwide or even globally. "The term virtual law firm has been popular in the news with the formation of Virtual Law Partners, Rimon Law Group, and FSB Legal Counsel-law firms that are made up of a conglomeration of lawyers that use technology to collaborate online while working remotely and reducing costs.",77

When Virtual Law Partners launched in 2008, the ABA Journal reported that the new venture would emphasize attorneys working from home with substantially reduced rates-dropping from $\$ 800$ to $\$ 400$ per hour, and allowing lawyers to retain $85 \%$ of their billable earnings. ${ }^{78}$ The

${ }^{72}$ Id. (citing PHILIP EVANS \& THOMAS WURSTER, BLOWN TO BITS 24-25 (2000)).

${ }^{73} \mathrm{KIMBRO}$, supra note 71 , at 1.

${ }^{74}$ Christine Lagorio, The Case Against "Sexy" Innovation, INC. (June 10, 2011), http://www.inc.com/articles/201 106/peter-sheahan-the-case-against-sexy-innovation.html (reporting on an interview with author and ChangLabs founder Peter Sheahan, who has written extensively about innovation and "Generation Y").

${ }^{75}$ KIMBRo, supra note 71 , at 1.

${ }^{76} \mathrm{Id}$. at 20.

7 Id. at 7; see FSB Legal CounSEL, http://www.fsblegal.com/ (last visited Feb. 26, 2013); RIMON LAW GRP., http://www.rimonlaw.com/law-firm-evolved (last visited Feb. 26, 2013); VIRTUAL LAW PARTNERS, http://www.vlplawgroup.com/ (last visited Feb. 26, 2013).

${ }^{78}$ Debra Cassens Weiss, At Virtual Law Firm, Lawyers Will Work at Home, Earn $85 \%$ of Billings, A.B.A. J. (July 16, 2008, 7:19 AM), http://www.abajournal.com/news/article/at_virtual_law_firm_lawy 
ABA Journal reported that the firm "hope[d] to employ hundreds of lawyers working from home doing all kinds of legal work for companies, except for litigation." 79

Contemporary news reports included both skeptics and supporters, but reports of two hundred or more resumes being sent to Virtual Law Partners suggest that the idea of working from home and setting one's own annual billable hour targets resonated strongly with attorneys. ${ }^{80}$

The virtual law firm replaces the law office hallways with web portals. It may very well develop that the interactions among attorneys within the firm on a closed, confidential social media system will allow for sufficient interactions to provide meaningful engagement, but it is hard to envision such a firm developing a culture of mentoring and training its associates. Without the mentoring and training functions, such virtual law firms will operate as parasites on more traditional firms, recruiting laterally from those firms that have trained their attorneys to be productive as lawyers and rainmakers.

This is not to say that a virtual law firm does not have the capacity to train its junior attorneys. CALI, the nonprofit computer-learning legal training provider, has developed an online course specifically on virtual lawyering. ${ }^{81}$ According to one report, "over 700 people registered for the course, and 270 attended the webinar [taught by Stephanie Kimbro]." The use of CALI lessons, online law school course offerings, webinars, and peer review could all be employed to assure quality control of the

ers_will_work_at_home_earn_85_of_billings/ ("Johnson, who will be CEO of the new firm, estimates that the average billing rate will be about $\$ 400$ an hour and says lawyers will get 85 percent of what they bill. There will be no billable hour requirements.").

${ }^{79}$ Id.

${ }^{80}$ See John Wallbillich, Virtual Law Partners-Initial Thoughts, WIRED GC (July 29, 2008), http://www.wiredgc.com/2008/07/29/virtual-law-partners-initial-thoughts/ (discussing the amount of interest in the virtual law firm). Among the comments were some interesting observations:

3. The level of attorney interest is striking. When you get 200 resumes in one week, you have struck a chord, and won't need to be using recruiters for awhile. Photos of real attorneys with lives outside the practice beats a boring recruiting brochure any day of the week.

4. The business model is bracing for VLP lawyers and clients. The lawyers get to keep more of the revenue they generate. This lets them make more or work less, or a combination of both. And the clients get as good or better service, without paying more for things they don't want (over-staffing) or need (expensive offices in highrent cities).

Id.

${ }^{81}$ CALI, Topics in Digital Law Practice Session 1: Virtual Law Practice (Feb. 10, 2012), http://tdlp.classcaster.net/2012/02/10/tdlp-class-1-virtual-law-practice-stephanie-kimbro-video-andslides/.

82 Stephanie Kimbro, Slides from CALI's Topics in Digital Law Practice Session, VIRTUAL L. PRACTICE (Feb. 10, 2012), http://virtuallawpractice.org/2012/02/slides-from-calis-topics-in-digital-lawpractice-session/. 
attorney work product and develop the attorneys within the systems. At the same time, however, those virtual law firms that organized precisely to avoid overhead and entanglement are less likely to invest in these steps, and the at-home work environment means that the serendipitous development of mentoring relationships has less opportunity to develop.

\section{The Law Firm Network}

A second form of reconstituted attorney practice model is the freemium marketing model. ${ }^{83}$ Companies such as Rocket Lawyer, Avvo, and Law Pivot offer free, introductory legal advice online in response to public queries. ${ }^{84}$ A participating lawyer answers questions for free on one of these sites and in return receives the site's recommendations as a trusted source for these simple questions. ${ }^{85}$ The people posting the questions are likely to be ready to hire an attorney, so the lead generation is rather effective. $^{86}$

LawPivot has taken the process a bit further, employing a form of search algorithm to select attorneys within its network from which to field the questions.

LawPivot started as a service through which users could ask questions privately and be matched to lawyers who could answer those questions through an algorithm identifying the right attorneys. It has since expanded to allow for questions to be asked and answered publicly, and now, to steer basic legal work to lawyers who participate. ${ }^{87}$

For those consumers who are looking for advice but not yet ready to invest in an attorney, these services provide a free introduction to the topics of interest. As these programs grow, the largest will establish network effects that make it difficult for a lawyer in need of new clients to avoid.

${ }^{83}$ See Chris ANDERSON, FreE: THE Future of A RAdICAL Price 26-27 (2009) (explaining the term freemium); see also Freemium, WIKIPEDIA, http://en.wikipedia.org/wiki/Freemium (last visited Mar. 13, 2013) ("Freemium is a business model by which a product or service (typically a digital offering such as software, media, games or web services) is provided free of charge, but a premium is charged for advanced features, functionality, or virtual products. The word 'freemium' is a portmanteau combining the two aspects of the business model: 'free' and 'premium'.").

${ }^{84}$ See, e.g., Avvo, http://www.avvo.com (last visited Mar. 14, 2012) ("Get free legal advice from top-rated lawyers.").

${ }^{85}$ See, e.g., LAWPIVOT, https://www.lawpivot.com/ (last visited Mar. 24, 2012).

${ }^{86}$ ROCKET LAWYER, http://go.rocketlawyer.com/Lawyer_Sign-Up.html (last visited Jan. 30, 2013). An explanatory page from Rocket Lawyer regarding its Rocket Lawyer On Call program offers the following: "Millions of potential clients use Rocket Lawyer every month . . . . You get real-time client requests by phone or email. . . . We've made the program free for you (no advertising costs)." Id.

${ }^{87}$ Kent Bernhard, Jr., LawPivot Crowdsources Legal Services, UPSTART BUS. J. (Dec.1, 2011, 1:20 PM), http://upstart.bizjournals.com/entrepreneurs/hot-shots/2011/12/01/law-pivot-crowdsourceslegal-services-adds-cash-faces-legalzoom-other.html?page=all. 
Just as Facebook came to dominate social media and Google to dominate search, any one of these companies could emerge with a large enough base of attorneys and clients to crowd out the other competitors. Rocket Lawyer has funding from both Lexis/Nexis and Google, ${ }^{88}$ so it has the support of some rather large players-companies that know how to dominate a marketplace. At the moment, however, the field is highly fragmented, so mere investment by owners dominant in other markets may mean little for the shape of the industry's future.

These networks consist of competing attorneys. A small adjustment to the model and the attorneys in the network could be participating in a massive virtual law firm. Assuming conflicts of interest are properly handled, the freemium model of introductory. advice and attorney matching can easily be combined with a client portal and with centralized, predictive document construction to create a truly massive new form of legal practice.

Assuming the LawPivot model of competing introductory answers and client satisfaction reports are used to promote the most effective attorneys within such a system, it could become both efficient and dominant in many markets. At the same time, however, it must be noted that the client often gets what he or she pays for. The attorney giving free advice is unlikely to have been given sufficient context or details to address any underlying issues or to be able to tailor general statements to the particular client issue. If the client walks away with such cursory advice, the information is little better than any other statement one can read online. The suggestion that information is personalized and provided by an attorney creates a risk of overreliance on what can only be the most general of suggestions. It epitomizes the concern that "a little knowledge is a dangerous thing." 89

\section{Settlement Mills}

A more disturbing move toward efficiency may be found in the lowvalue, high-volume world of personal injury settlement. Here the model relies quite heavily on paralegal production rather than computer-generated content. An excessive zeal for efficiency combined with other shortcuts can quickly devolve into "settlement mills." Where a firm designs its

88 Dean Takahashi, Rocket Lawyer Raises \$18.5M for Web-Based Do-It-Yourself Legal Assistance, VENTUREBEAT (Aug. 11, 2011, 4:30 AM), http://venturebeat.com/2011/08/11/rocketlawyer-raises-18-5m-for-web-based-do-it-yourself-legal-assistance/\#apL2CxDV0XdAiZU4.99.

${ }^{89}$ See $A$ Little Knowledge Is a Dangerous Thing, PHRASE FINDER, http://www.phrases.org.uk/meanings/a-little-knowledge-is-a-dangerous-thing.html (last visited Jan. 30, 2013) (explaining the phrase's origin as a quote by Alexander Pope in An Essay on Criticism from 1709).

${ }^{90}$ Nora Freeman Engstrom, Run-of-the-Mill Justice, 22 GEO. J. LEGAL ETHICs 1485, 1486 (2009) ("'[S]ettlement mills' - high-volume personal injury law practices that aggressively advertise and mass produce the resolution of claims, typically with little client interaction and without initiating lawsuits, much less taking claims to trial."). 
business model on the volume of clients it serves and pays little heed to the quality of representation it provides, the firm does a tremendous disservice to its clients. This is particularly troubling in the case of personal injury claims, where the victims are unlikely to be repeat players so they are not well equipped to make informed decisions regarding the proffered representation. ${ }^{91}$ "[T] here are many kinds of personal injury lawyers. . . . Choosing a lawyer wisely is thus extremely important. It is also, as we will see, extremely difficult. . . . [E]ven the most basic information on attorney quality remains stubbornly elusive., ${ }^{, 2}$

These settlement mills rely on centralized advertising to promote their clientele and build their business base. ${ }^{93}$ Professor Nora Freeman Engstrom focuses on ten attributes of the settlement mill:

Ten characteristics help to distinguish settlement mills from more conventional personal injury law firms. Four of these factors are necessary (meaning a law firm that does not exhibit each characteristic cannot be considered a settlement mill), and six represent traits that are probative. Settlement mills necessarily (1) are high-volume personal injury practices that (2) engage in aggressive advertising from which they obtain a high proportion of their clients, (3) epitomize "entrepreneurial legal practices," and (4) take few-if any-cases to trial. In addition, settlement mills generally (5) charge tiered contingency fees; (6) do not engage in rigorous case screening and thus primarily represent victims with low-dollar claims; (7) do not prioritize meaningful attorney-client interaction; (8) incentivize settlements via mandatory quotas or by offering negotiators awards or fee-based compensation; (9) resolve cases quickly, usually within two-to-eight months of the accident; and (10) rarely file lawsuits. ${ }^{94}$

The pejorative designation of mill should reflect more than a dislike of non-traditional legal efficiency. ${ }^{95}$ Instead, it is the mandatory settlement

${ }^{91}$ Id. at 1524 ("Settlement mill attorneys can afford to spend comparatively little time cultivating such relationships, presumably because they recognize that they need not rely on repeat clients or word-of-mouth in order to obtain a steady stream of new business.").

${ }^{92}$ Nora Freeman Engstrom, Sunlight and Settlement Mills, 86 N.Y.U. L. REV. 805, 812 (2011).

${ }^{93}$ Engstrom, Run-of-the-Mill Justice, supra note 90, at 1524.

${ }^{94} \mathrm{Id}$. at 1491-92.

${ }^{95}$ See SUSSKIND, supra note 24, at 27 ("A word about terminology is needed at the outset. When most lawyers speak today about 'commoditization', they generally do so reluctantly and frequently do so through gritted teeth."). A "settlement mill" is a far more loaded term for the commoditization of personal injury practice where the values involved do not warrant the expense of in-depth investigation and protracted trial. The term should be reserved for those firms that harm their clients by taking unfair advantage in an unethical manner, not merely because the firm operates at a high rate of volume. 
quotas, negotiators fee-based compensation, and lack of diligence that make such business models harmful. One can hardly fault a law firm for quickly resolving disputes and doing so without the expense of a trial-but only if the outcome is reasonable for the client. ${ }^{96}$ Even Professor Engstrom recognizes that "settlement mills offer a service." If segments of the bar focus on the efficiency and lack of costly trials, the public will reject efforts at regulation. To distinguish between the efficient success story and the predatory settlement mill, state supreme courts and legislators must look at which types of conduct actually harm the prospective clients. ${ }^{98}$

One other possible benefit is that these highly visible, advertisingdriven firms create sufficient scale that they may receive public scrutiny in ways that smaller firms are likely to avoid. Social media works because the network effect of participants brings together enough people with sufficient interest to address an issue. If law firms of the type described by Professor Engstrom are harming their clients, hopefully the number of complaints will trigger direct and substantial review.

\section{THE LAWYER UNBOUND: RISE OF THE NETWORKED LAWYER}

To respond to the changes wrought by technology, practitioners in all settings must adapt. They must recognize the "technological change that transformed business and often undermined industry incumbents in favor of start-up competitors." 99 This process, known as disruptive innovation, requires that incumbents actively create business models that undermine

${ }^{96}$ See generally Marc Galanter, The Vanishing Trial: An Examination of Trials and Related Matters in Federal and State Courts, 1 J. EMPIRICAL LEGAL STUD. 459, 524-29 (2004) (discussing the possible ramifications of the decrease in trials by jury).

What reasonable means in this context is also multifaceted. For many injury victims, the speed of resolution, the lack of disruption from a trial, certainty of outcome, and closure of the incident would support a quick settlement, even at a somewhat reduced reward. But if the victim is charged excessive fees or receives only a highly discounted settlement, then the cost becomes too high and the outcome is no longer reasonable. The ultimate difficulty is that a tort victim has no meaningful way to compare potential forms of representation and make an informed decision. See Engstrom, Sunlight and Settlement Mills, supra note 92, at 835-36 (discussing the tradeoffs implicit in the settlement mill structure).

${ }^{97}$ Engstrom, Sunlight and Settlement Mills, supra note 92, at 810-11 ("It is, I believe, a valuable service. But it is, in many respects, a different service than that offered by conventional counsel, and there is little reason to believe that settlement mill clients-particularly unsophisticated clients with high-value claims-have intentionally selected or consented to this altemative regime.").

98 See Engstrom, Run-of-the-Mill-Justice, supra note 90, at 1518 ("Twenty to thirty years ago, you could go to any town and there were little mom and pop retailers. Same has happened with personal injury. If you go to any city, there will be three or four firms getting $90 \%$ of the cases." (quoting Telephone Interview with D.R. [unidentified source] (Apr. 3, 2008))); see also id. at 1519 n.217 ("If you look at the top 50 media markets in the country and then break down the number of firms in those markets spending a half million or more per year on TV, you will have found your settlement mills." (quoting e-mail from D.R. [unidentified source] to author (Apr. 4, 2008))).

${ }^{99}$ Garon, Mortgaging the Meme, supra note 4, at 442. 
their existing market dominance. ${ }^{100}$ Law is not immune to the broader shifts in economic trends. "For many, their core businesses are being disrupted by globalization, technology shifts, and new competitors. They must reinvent the company. Even at healthy companies, business model innovations are essential to retaining their competitive positions."

Critics of change will decry the transformation. ${ }^{102}$ The recitation of the imminent collapse of the profession and the decline into baseless business tactics have been oft-repeated laments. ${ }^{103}$ Writing in the early 1930 s, New Jersey Bar President Ralph Lum stated:

Our calling has passed from a learned profession of picked leaders to a heavily crowded business. . . . When a learned profession, content with honorariums, was transformed into a business where specialized training was used to make fortunes, we inevitably and inescapably attracted a large class who have ever, and ever will turn where a golden harvest seems most promising. ${ }^{104}$

Dean Thomas Morgan writes that lawyers must abandon the label of the profession in order to address the coming changes. "Lawyers should, however, remove the lenses of professionalism through which they have been encouraged to see their futures."105 Looking at lawyering in such a stark light is not necessary. Instead, it is enough to recognize that the business of lawyering has changed. In this way, the values of professionalism will not be diminished and perhaps we will begin to translate those goals into practices in a more effective manner.

Despite all protestations, the profession of lawyer has forever been entwined with the business of lawyering. ${ }^{106}$ This requires that the attorney

${ }^{100}$ CHRISTENSEN, supra note 68 , at xiii.

101 Mistakes Made on the Road to Innovation, BLOOMBERG BuSINESSWEEK (Nov. 26, 2006), http://www.businessweek.com/magazine/content/06_48/b4011421.htm.

102 See, e.g., RENNARD STRICKLAND \& FRANK T. READ, THE LAWYER MYTH, at xiv (2008) (noting that in comparison to growing attacks on the legal profession, "[we, the authors,] have watched thousands of America's brightest, most spiritually centered, profoundly competent, deeply determined, and dedicated young women and men pass through law school to join the ranks of attorneys, counselors at law, and judges. We believe in them and in their enterprise").

${ }^{103}$ See RosCoe POUND, AM. BAR ASS'N, THE LAWYER FROM ANTIQUITY TO MODERN TIMES 353-62 (1953) (describing threats to the idea of lawyering as a profession).

104 ALEXANDER L. SCHLOSSER, “LAWYERS MUST EAT" 29 (1933) (quoting New Jersey Bar President Ralph Lum at the New Jersey State Bar Association).

${ }^{105}$ MORGAN, supra note 9, at 69.

${ }^{106}$ See id. at $64-67$ (discussing the problem professionalism creates in addressing the fees and business aspects of a lawyer's education and practice); see also Thomas D. Morgan, Calling Law a "Profession" Only Confuses Thinking About the Challenges Lawyers Face, U. ST. THOMAS L.J. (forthcoming), available at http://ssm.com/abstract=2007296 (comparing the law as an occupation to the law as a profession and concluding "the law is not a profession and that's a good thing" (quoting MORGAN, supra note 9, at 66)). While I share the view by other critics that law is a profession, it 
provide services the client wants in a manner the client wants them. In the information age, this means that an ever-increasing venue for purchases, medical services, media, and social interactions are online. ${ }^{107}$ The public is also highly global, with jurisdictional borders becoming increasingly permeable and fluid. ${ }^{108}$ "[T]he information revolution has been changing the world profoundly, irreversibly and problematically since the fifties, at a breathtaking pace, and with unprecedented scope, making the creation, management and utilisation of information, communication and computational resources vital issues.",109

Since the business of the lawyer is lawyering, treating law as a business does not diminish the attributes of careful, professional legal services. ${ }^{110}$ To the contrary, it puts them at a premium. The lawyers' roles as confidential confidant, counselor, and zealous advocate ${ }^{111}$ are all sold as

remains a business as well and, as such, the practicing bar and the educators must pay closer attention to operations side of the house. See John M. Conley, Is Law Really a Profession?, 24 GEO. J. LEGAL ETHICS 1183, 1187-89 (2011) (reviewing THOMAS D. MORGAN, THE VANISHING AMERICAN LAWYER (2010)) (agreeing with Morgan's assessment that legal work will become "de-professionalized" and become business-orientated); Neil Hamilton, The Profession and Professionalism Are Dead?, 20 PROF. LAW 2, 14 (2010) (reviewing THOMAS D. MORGAN, THE VANISHING AMERICAN LAWYER (2010), and arguing that Professor Morgan's proposed alternative is flawed in terms of benefit for the public good).

${ }^{107}$ See generally MANUEl CASTELlS, THE RISE OF THE NETWORK SOCIETY: THE INFORMATION AGE: ECONOMY, SOCIETY, AND CULTURE VOLUME I, at 164-65, 187-88 (Wiley-Blackwell 2d ed., 2010) (describing the network enterprise, where consumers in the global economy expect efficiency, adaptability, and flexibility).

${ }^{108}$ See Jon M. Garon, Rethinking Intangible Cultural Heritage and Expressions of Folklore: $A$ Lesson from the FCC's Localism Standards, DENV. SPORTS \& ENT. L.J. (forthcoming 2012), available at http://works.bepress.com/jon_garon/2/(describing how national borders have decreasing importance in a networked, globalized community).

${ }^{109}$ Id. (quoting Luciano Floridi, The Information Society and Its Philosophy: Introduction to the Special Issue on "The Philosophy of Information, Its Nature, and Future Developments," 25 INFO. Soc'Y 153, 154 (2009), available at http://www.philosophyofinformation.net/publications/ pdf/tisip.pdf).

110 See MORGAN, supra note 9, at 66-69 (discussing how various institutions such as the Government, the ABA, and large firms affect lawyering professionalism).

11 See Robert Rubinson, The Model Rules of Professional Conduct and Serving the Non-Legal Needs of Clients: Professional Regulation in a Time of Change, 2008 J. PROF. LAW. 119, 120 (2008) (describing the traditional view of lawyering as "zealous representation").
Abraham Lincoln offered words of advice to lawyers: "Discourage litigation. Persuade your neighbors to compromise whenever you can. As a peacemaker the lawyer has superior opportunity of being a good man. There will still be business enough." Even earlier, Alexis de Tocqueville, in an oft-quoted observation during his travels in 1820's America, noted "[lawyers] serve as arbiters between the citizens." Yet another famous example is the notion of "lawyer for the situation" attributed to Louis Brandeis, the essence of which rejects slavish adherence to the interests of one client, and rather suggests that lawyers should facilitate common goals among multiple parties.

Id. at 121 (alteration in original) (quoting Abraham Lincoln, Notes for a Law Lecture, in THE LIFE AND WrITINGS OF ABRAHAM LINCOLN 329 (Philip Van Doren Stern ed. 2004)); Carrie Menkel-Meadow, The Lawyer as Consensus Builder: Ethics for a New Practice, 70 TENN. L. REV. 63, 72 (2002) (quoting 
premium services that benefit primarily from the fidelity of an impeccable reputation. ${ }^{112}$ In an age of ubiquitous media and shared customer reviews, brand is more important than ever. This "would seem to lend support to the claim that a 'brand name' for client devotion will be an increasingly important firm asset." 113

For the information age, this means that the actual practice of law, not merely the advertising of legal services, should be mediated though digital communications. The new breed of lawyers will be (1) technologically savvy, treating technology as a tailwind rather than a headwind; (2) efficient and economical, particularly with regard to limiting overhead; (3) highly networked; (4) specialized; (5) unbundled purveyors of limited services; (6) scalable; and (7) profitable. The best will also be (8) socially responsible and civically engaged; (9) exemplifying work-life balance and cultural sensitivity; and (10) valued intermediaries providing highly personalized consultative advice.

The first half of this list is a reaction to the foibles of the twentieth century law firm and the steps taken by the virtual law firms to dismantle those models. The latter half of the list focuses on the ideals of professionalism, ethics, and personal ethos that brought many lawyers into the practice of law and serve as the rewards for those who are most successful.

Interestingly, in this model, one attribute that is not relevant is size. The distinction between the solo practitioner and Big Law lawyers has bearing neither on the attributes of the successful new firm, nor on the nature of the lawyer's practice. Size has had a significant impact on

\footnotetext{
AleXIS DE TOQUEVILLE, DEMOCRACY IN AMERICA 243 (J.P. Mayer \& Max Lerner eds., George Lawrence trans., 1966)); Clyde Spillenger, Elusive Advocate: Reconceptualizing Brandeis as People's Lawyer, 105 YALE L.J. 1445, 1502-11 (1996); see also Joseph A. Colquitt, Evidence and Eihics, Litigating in the Shadow of the Rules, 76 FORDHAM L. REV. 1641, 1666 (2007) (describing the lawyering paradigm as "zealous advocacy"); Edward D. Re, Professionalism for the Legal Profession, 11 FED. CIR. B.J. 683, 689-90 (2001) (noting that lawyers must represent their clients zealously, but also that they are officers of the court subject to rules of law, professional responsibility, and professional ethics); Eli Wald, Loyalty in Limbo: The Peculiar Case of Attorneys' Loyalty to Clients, 40 ST. MARY's L.J. 909, 929 (2009) ("[W] hile the common professional ethos identified the lawyer's primary duty as one owed to clients, it did not fail to specify duties to the court and the public ...."); Douglas H. Yarn, The Attorney as Duelist's Friend: Lessons from the Code Duello, 51 CASE W. RES. L. REv. 69, 70 (2000) (applying lessons from dueling codes to balance zealous advocacy and peacemaker roles for attorneys).

${ }^{112}$ See Milton C. Regan, Jr., Professional Reputation: Looking for the Good Lawyer, 39 S. TEX. L. REV. 549, 550 (1998) (describing the tension between the concept of professionalism and the need to maximize profits, and how the professional reputation may depend on the type of practice).

${ }^{113}$ See also id. at 560 ("To the extent that client loyalty traditionally has served as the 'standard conception' of the lawyer's role, a reputation for adhering to that role would seem to be of ever greater importance in modern law practice.").
} 
profitability, ${ }^{114}$ and it may continue to do so, though success of the virtual law firms have the potential to distintermediate the current hegemony of the multinational Big Law firms.

\section{A. Technological Savvy}

As this Article suggests, the successful lawyer must meet her clients where they live, which today must be conveniently located near the information superhighway. Technologically savvy does not necessarily require that the firm is an early adopter of virtual client portals (though these will eventually become ubiquitous) or that the lawyer practices intellectual property or information technology law. But it does require certain minimums:

- that all systems are computerized and centralized;

- that the " $\mathrm{e}$ " in eDiscovery is eliminated with the understanding that a litigator can no longer make a discovery request entirely devoid of electronic records;

- that the firm has clear policies regarding the integrity and security of client communications and information so that duties of confidentiality are maintained;

- that the firm has clear policies and operations regarding the confidentiality and security of its own digital records;

- that it respects its client's need to communicate efficiently through a variety of media including telephone, teleconference (Skype, WebEx, GoToMeeting, FaceTime, etc.) email, text, and secure social media; and

- that every attorney knows whether a particular communication is secure or public.

The American Bar Association has adopted changes to the ABA Model Rules of Professional Conduct including the addition of Section 1.6(c), which will explicitly require that "[a] lawyer shall make reasonable efforts to prevent the inadvertent or unathorized disclosure of, or unauthorized access to, information relating to the representation of a client." 115 Moreover, as noted in the proposed comments,

114 See JOHN HEINZ ET AL., URBAN LAWYERS 174 (2005) ("[T]he types of organizations in which lawyers worked came to have greater effects on their pay, even after the differences between organizations in lawyers' work experience and performance in legal education were taken into account.").

115 ABA COMMISSION ON ETHICS 20/20 REVISED DRAFT RESOlutions FOR COMMENT$\begin{array}{lllllll}\text { TECHNOLOGY AND CONFIDENTIALTY } & 8 & (2012), & \text { available }\end{array}$ 
Whether a lawyer may be required to take additional steps to safeguard a client's information in order to comply with other law, such as state and federal laws that govern data privacy or that impose notification requirements upon the loss of, or unauthorized access to, electronic information, is beyond the scope of these Rules. ${ }^{116}$

The changes to the Model Rules of Professional Responsibility highlight the centrality of these requirements for all practicing lawyers. Technological competence is no longer optional for the practice of law.

\section{B. Efficient and Economical}

The issue of economic efficiency poses a broader challenge than mere cost containment. Real estate lease costs represent some of the largest fixed costs faced by law firms. ${ }^{117}$ Leases also tend to be quite inelastic, such that a firm struggles when it has too few offices and then rapidly loses money whenever it downsizes. Moreover, lavish build-outs serve to send a strong marketing message to clients and potential new hires that a firm is successful, but such spending constitutes a drag on income and a suggestion of profligacy in management. ${ }^{118}$

This does not suggest that most firms will move to virtual law firms operated out of attorney homes. Among other problems, that model places the cost of space on the individual attorney, assumes a self-discipline that is not universal, and ignores the benefits of strategic office locations and shared spaces. Well-designed offices promote collaboration among attorneys, encourage client/lawyer interactions, create opportunities to engage potential clients, and promote efficiency. Each firm will identify the preferred space depending on its needs and the needs and expectations of its clients. The key will be to maximize the efficiency of choices surrounding space so that an effective mix of locations can be used and locations are selected based on all these factors rather than merely on prestige.

Space represents only one aspect of overhead. Attorneys, staff support, marketing costs and other expenses all reflect strategies that a firm should carefully consider to maximize the impact of investment in the firm. Those law firms which intentionally review their operational costs with a focus on maximizing the impact of the budget on the strategic goals of the

http://www.americanbar.org/content/dam/aba/administrative/ethics_2020/20120221_ethics_20_20_revi sed_draft_resolution_and_report_technology_and_confidentiality_posting_final.authcheckdam.pdf.

${ }^{116} \overline{I d}$. at 12 .

117 Jennifer Smith, Law Firms Squeeze More into Less-Practices Ditch Comer Offices, Switch to Glass Walls in Attempt to Cut Costs, Improve Cooperation, WALL ST. J., July 16, 2012, at B4.

${ }^{118}$ See id. (noting that more expensive office items that formerly symbolized success are harder to come by in modern firms). 
firm will increasingly outperform their counterparts. ${ }^{119}$

Technology is not necessarily a cost saver. Early adoption of inefficient software, purchase of software without budgeting commensurate training and other traps await anyone who thinks technology is a panacea for the future. Only through careful benchmarking and development of clear goals will a firm succeed to become efficient and effective for its clients and itself.

\section{Highly Networked}

The successfully networked lawyer must be networked within both the legal community and the clients' sphere of operations. Because technology has the potential to disintermediate an individual from other human contact, the successful lawyer must design positive human interaction into his or her daily schedule. Training and mentoring must move from casual to systematized so they actually take place. Whether working at home or in a practice group spread over five cities and time zones, the attorneys must make an effort or they will quickly face isolation.

The need to network is a fundamental social need, but the focus here is on its key professional attributes. To move a firm from a commodity provider to an essential player for the client, each attorney touching a file should be looking for opportunities to involve other lawyers who can add critical insight and important value for that client. While no one likes to be "upsold," if the expert advice pays for itself, the client is pleased and becomes increasingly reliant on the firm as a source of trust. ${ }^{120}$ The ability of a lawyer to know precisely who within the firm can add that valuable additional insight may be aided by software tools, but it is primarily the personal knowledge one has about one's colleagues that matters. After all, sometimes the personality of the advice provider is every bit as important as the information itself. Similarly, for the lawyer to grow, mature, and become more valuable, that individual must continually be learning new skills, increasing in authority and justifying the inevitable increases in rates

119 A personal anecdote highlights this distinction. While dean of Hamline Law School, I often discussed our faculty sabbatical policy with managers of major law firms in the Minnesota market. Most were quite jealous of this benefit for the faculty members. Although I reminded the law firm partners that the "cost" was $1 / 14$ of a faculty member's compensation (one semester off each seven years), the law school also received scholarly work product and a strong impact on retention. Even though many of these law firms had significant retention challenges for which even modest changes in retention rates would greatly exceed the cost of the policy, no firm was willing to study how to implement this highly desirous benefit.

120 See Allison Shields, Cross-Selling, Up-Selling, and Communication Increase Revenue, LAWYERIST.COM (Mar. 7, 2012), http://lawyerist.com/cross-selling-up-selling-and-communicationincrease-revenue/ ("Up-selling is offering a client an upgraded or premium level of service at an increased fee. . . . An 'up-sell' is not giving the client something they don't need-it is simply offering them a higher level of service with a corresponding increase in the value to the client."). 
that come with advancement in a firm. Internal and external training and mentoring are critical for this growth. Without it, individual lawyers will stagnate and either leave or underperform.

Networking in the clients' sphere is equally crucial to success. As competition intensifies and geographic barriers decrease, a law firm of the future must become essential to its clients in order to retain them. There will always be competitors who offer lower cost alternatives. Survival demands adding value for a client. To do this, whether for corporate clients or when representing individuals, lawyers must understand the constraints of the industry and the external factors shaping clients' decision making.

A classical sociological theory of lawyers posits three steps: "diagnosis, inference and treatment."121

During diagnosis, the client's problem is translated into professional terms. Inference reformulates the problem using the abstract knowledge and conceptual apparatus of the profession, and the professional applies or manipulates that knowledge in order to solve the problem, as defined in professional terms. Treatment provides the client with the solution and involves translating the problem from professional terms back into the specific, real-world context of the client. ${ }^{122}$

This dissection of the lawyering process highlights the distinction between the book-learned graduate who understands every inference of the problem, but is unable to treat the client's problem, from the seasoned attorney who may spend far less time on the analysis because she knows which treatment options are available and how best to focus on the treatable aspects of the problem. The lawyer's treatment of the client's problem comes from context and active engagement. This step must be hard-wired into the operations of the law firm to make it competitive.

\section{Specialized}

The more an attorney focuses on networking with one's clients and peers, the more likely that person will specialize in a particular area of law. While technically a lawyer should be able to make himself or herself competent to handle any area of the law, the time and effort to do so will be paid by the attorney. Clients will not-and likely should not-be forced to pay hourly rates for an attorney who needs on-the-job training for

${ }^{121}$ HEINZ ET AL., supra note 114, at 80; see Andrew Abbott, Status and Strain in the Professions, 86 AM. J. Soc. $819,819-33$ (1981) (discussing the relationship between the steps of inference, diagnosis, and treatment).

122 HEINZ ET AL., supra note 114 , at 80. 
a new field of practice. An attorney's network of peers and clients will be much stronger if it is not scattered across a wide array of unrelated practices. The recommendation of specialization may apply at the firm level as well. ${ }^{123}$

Focus on a particular practice will enable the firm to maximize the efficiencies of its knowledge with greater focus on its primary revenue, greater attention to its key clients, better use of documents and other resources, and many related efficiencies. Particularly if the potential billable time of the attorneys (however charged to the client) is limited, focusing that capacity on a clear target will likely result in the capacity being maximized without running out of control. Specialization becomes a corollary of efficiency and networking.

Such specialization may include expansion, as well. As the firm specializes in a particular topic, it may directly or indirectly network to provide a range of services to meet its clients' needs. ${ }^{124}$ While the regulation of both multidisciplinary practice and multijurisdictional practice is beyond the scope of this Article, it should not be overlooked, since it will undoubtedly be part of the revenue strategy for attorneys and firms. The only question will be the extent to which the non-legal or nonjurisdictional aspects of these operations are linked to ownership and structure of the law firms and, in consequence, the ability of the profession to regulate those activities.

\section{E. Unbundled Purveyors of Limited Services}

Directly linked to the concept of specialization is the understanding of what work an attorney will not undertake. An efficient law firm should only undertake that which it can do efficiently and do efficiently that which

${ }^{123}$ See Steven M. Gursten, A.B.A. LAW PRACTICE MGMT. SECTION, Niche Specialization for Lawyers, LAW PRACTICE TODAY (Mar. 2011), http://www.americanbar.org/content/dam/aba/publicatio ns/law_practice_today/niche_specialization_for_lawyers.authcheckdam.pdf (describing a firm that specializes in Michigan automobile accidents and how this specialization differentiates and distinguishes the firm from other lawyers).

124 See MODEL RULES OF PROF'L CONDUCT R. 5.7 (2012) (regulating "services that might reasonably be performed in conjunction with and in substance are related to the provision of legal services, and that are not prohibited as unauthorized practice of law when provided by a nonlawyer"); see also Stephen Gillers, Waiting for Good Dough: Litigation Funding Comes to Law, 43 AKRON L. REV. 677, 679-80 (2010) (noting that the ABA permits ancillary legal services under certain conditions and any concern that such business would expose lawyers to liability does not have merit); Robert $\mathbf{R}$. Keatinge, Multidimensional Practice in a World of Invincible Ignorance: MDP, MJP, and Ancillary Business afier Enron, 44 ARIZ. L. REV. 717, 725 (2002) (observing that while the ABA model rule governing ancillary businesses has not been widely adopted, most states do not forbid a law firm from providing ancillary servies); Carole Silver, What We Don't Know Can Hurt Us: The Need for Empirical Research in Regulating Lawyers and Legal Services in the Global Economy, 43 AKRON L. REV. 1009, 1016 (2010) (discussing lack of empirical data on multidisciplinary and multijurisdictional practice). 
it undertakes. While ethical canons suggest that a lawyer cannot refuse to take a client, such a rule is more hortatory than real. ${ }^{125}$ The Rules of Professional Conduct focus on court-appointed counsel-not the duty to engage every client who sends an email-and contain critical limitations. ${ }^{126}$

Providing limited services has two dimensions. First, the firm must identify what subject matters fall within its core competencies and which would be too costly or inefficient to undertake. Since the explicit limits of representation are required for an attorney, ${ }^{127}$ this should not be controversial. As firms increasingly specialize, fee agreements must specify the scope and capacity of a firm's service. For example, an intellectual property boutique may actually operate exclusively as a patent prosecution firm that does not undertake any trademark or copyright representation or even any patent litigation. A clear fee-services agreement allows the firm to provide a particular service. ${ }^{128}$ As a benefit, other firms recognize the limitations of such a boutique and become more willing to refer work without fear that their activities will be poached by the boutique's fee-hungry attorneys.

Second, within a firm's core competence, it must identify what types of service will benefit its clients and what services will leave the clients with only partial solutions that may tend to aggravate, rather than ameliorate, the client's concerns. This aspect of limited services raises professional and ethical concerns that every law firm must address.

In the context of pro se, or often indigent clients, there remains some controversy regarding this approach to practice, known as unbundled legal services. ${ }^{129}$ This phrase is taken to refer "to the idea that legal assistance can be broken down into 'discrete tasks such as giving advice, preparing documents and appearing in court."'130 Simply put, if a pro se client

${ }^{125}$ See Teresa Stanton Collett, The Common Good and the Duty to Represent: Must the Last Lawyer in Town Take Any Case?, 40 S. TEX. L. REV. 137, 168 (1999) (arguing that the last lawyer in town is no more obligated to provide legal services than the first).

${ }^{126}$ See MODEL RULES OF PROF'L CONDUCT R. 6.2 (2012) ("A lawyer shall not seek to avoid appointment by a tribunal to represent a person except for good cause, such as: (a) representing the client is likely to result in violation of the Rules of Professional Conduct or other law; (b) representing the client is likely to result in an unreasonable financial burden on the lawyer; or (c) the client or the cause is so repugnant to the lawyer as to be likely to impair the client-lawyer relationship or the lawyer's ability to represent the client." (emphasis added)).

${ }^{127}$ Samuel A. Thumma \& Lynda C. Shely, Fee Agreements A to Z, 38 ARIZ. ATT'Y 22, 23 (2002).

${ }^{128}$ Id.

${ }^{129}$ Mark H. Tuohey III et al., Handbook on Limited Scope Legal Assistance, A Report of the Modest Means Task Force, 2003 A.B.A. SEC. OF LITIG. 4-5 (2003) [hereinafter Limited Assistance Handbook], available at http://apps.americanbar.org/litigation/taskforces/modest/report.pdf ("By 'limited scope legal assistance,' we mean a designated service or services, rather than the full package of traditionally offered services. The client and lawyer select the service the lawyer will provide.").

${ }^{130}$ Brenda Star Adams, Note, "Unbundled Legal Services": A Solution to the Problems Caused by Pro Se Litigation in Massachusetts's Civil Courts, 40 NEW ENG. L. REV. 303, 327 (2005) (quoting 
comes to an attorney for help understanding how to fill out a form in order to attend a court or administrative hearing, the party would likely be better off if the attorney instead represented the person at the hearing. For attorneys who would be willing to provide a modicum of consultation to help with the form, but not undertake full representation, a rule that requires all-or-nothing representation will result in the attorney refusing to help at all. ${ }^{131}$ And without the form, the person cannot be heard before the tribunal, so the person is harmed by the lack of limited assistance.

While the debate of unbundled legal service is beyond the focus of this Article, it is important to point out that the scenario is by no means limited to the indigent pro se client. Limited scope assistance is not new. ${ }^{132}$ Instead, it intersects with the growth of the self-help movement. Today, small business owners are drafting operating agreements and private placement memoranda while individuals are completing contracts, wills, estate plans and employment agreements-all without legal representation. When a client comes to an attorney with such a document in hand, the work has already been unbundled. But the lawyer must tread very carefully to allocate enough time and budget enough cost to review such self-help in a comprehensive manner so that the client has received a full and complete assessment of that matter. ${ }^{133}$

While there are considerable ethical and practical considerations, the importance of the limited practice attorney should not be overlooked. The key to avoiding malpractice is for the law firm to carefully identify the minimum level of information necessary for such a client and make clear in the ex ante representation agreement both the limitations on the representation and the thresholds for representation.

Elizabeth Amon, Lawyers Worry a Little Bit of Help Could Mean Liability in Pro Se Cases, MIAMI DAILY BUS. REV., Aug. 1, 2002, at 9).

${ }^{131}$ See Recommendations of the Conference on the Delivery of Legal Services to Low-Income Persons, 67 FORDHAM L. REV. 1751, 1759-60, 1766-67, 1778 (1999) (Recommendations 25, 34-36, 63) [hereinafter Recommendations] (making recommendations that non-lawyers be allowed and encouraged to help indigent clients and lawyers be encouraged to disseminate knowledge more broadly but reserving for further study such activities as unbundling of legal services); see also Mary Helen McNeal, Having One Oar or Being Without a Boat: Reflections on the Fordham Recommendations on Limited Legal Assistance, 67 FORDHAM L. REV. 2617, 2646-47 (1999) (agreeing with the recommendation that divides limited legal assistance into two categories: "brief, specific advice" and "services requiring a diagnostic interview" (quoting Recommendations, supra, at 1776-77) (Recommendation 60))); Mary Helen McNeal, Redefining Attorney-Client Roles: Unbundling and Moderate-Income Elderly Clients, 32 WAKE FOREST L. REV. 295, 339 (1997) (recommending that while unbundling may be a practical alternative for providing legal assistance, a pilot project should be utilized to determine whether it would assist those in need).

132 Limited Assistance Handbook, supra note 129 , at 5.

133 "This also occurs in litigation when in-house counsel work on a team with outside counsel, with discrete tasks assigned to each." Id. at 6 . 


\section{F. Scalable}

Firms that can grow or shrink in proportion to the demands of the marketplace will have a tremendous advantage over both firms that carry heavy overhead and those that lose clients because they cannot add resources to meet the clients' needs. All the operations within a law firm should be scalable to the demands of the market. "Novice business owners, who haven't considered the impact of growth, are often blindsided by the complexities of scaling their operations. . . . The smarter lawyer will setup a practice with an eye towards the future, ensuring cash continues to flow as new people are brought on board."134 This observation regarding scale at the outset of practice remains equally true throughout the lifespan of a firm.

Among the techniques firms can use to increase their scalable services are the ability to use technologically mediated interfaces, such as those championed by the virtual law firms, to employ a combination of leaseholds that allow for short-term use of space rented on an as-needed basis, a network of lawyers who can come together on projects without being full-time employees of the firm, and careful measures of operations as well as billable hours to determine the efficiency of a firm's professional capacity.

Scalability starts with the structural purchases of systems including telephone ${ }^{135}$ and computer systems. ${ }^{136}$ Outsourcing technology and other needs such as eDiscovery allows a firm to avoid investing in expensive and quickly changing technology. ${ }^{137}$ Leveraging the scalability of real estatesuch as by renting in buildings that have shared conference rooms and large event spaces-gives even the most traditional firms the ability to reduce their per-square-foot costs while still meeting all full-service needs.

"The flexibility of the technology encourages innovation and entrepreneurship for lawyers willing to invest in a more complex law firm structure."138 For example, scalability may include collaborations among law firms. The Association of Corporate Counsel ("ACC") has highlighted this strategy as a successful method of reducing costs and gaining needed

\footnotetext{
${ }^{134}$ Larry Port, Inexpensive, Scalable Phone System, LAWYERIST.COM (Nov. 11, 2010), http://lawyerist.com/inexpensive-scalable-phone-system/.

${ }^{135}$ See id. (describing a new scalable phone system for law firms that can provide extensions, queuing, and a phone number).

${ }^{136}$ See, e.g., Gavin Ward, Cloud Computing for Lawyers: A Lawyer Looks at LawCloud, LAWCLOUdCOMPUTING (Jan. 10, 2011), http://lawcloudcomputing.com/tag/scalability-and-cloudcomputing/ (observing the benefits of a product that stores data and platforms on servers located outside the law office, known as cloud computing).

${ }^{137}$ Kevin Nichols, Scalability Defined and Why It is Important, DigITALREEF (Nov. 07, 2011, 3:28 PM), http://www.digitalreefinc.com/blog/bid/77305/Scalability-Defined-and-Why-it-is-Important.

${ }^{138}$ KIMBRO, supra note 71, at 29.
} 
capacity. ${ }^{139}$ The three law firms analyzed by the ACC were distinct, but effectively integrated. "The three firms are closely connected via information technology. Extranets are available for coordination amongst the three firms as well as communication with their clients. They work off compatible information systems."140 Beyond their own technological network, these firms then maintain "close ties with a strong network of law firms around the country (ranging from large to small), enabling the firm to tap into additional expertise as needed to address local counsel needs and specialized areas of expertise as may become necessary." ${ }^{\text {"141 }}$ Such collaboration highlights the potential positive attributes of scalability.

The dark side of scalability is the decrease in job security that it may engender. By turning members of the firm into "of counsel" (independent contractors), the firm pushes the risk of economic downturn on those attorneys. Economically, however, it might also keep them employed. When law firms retrench, they typically jettison associates, leaving them out of work and utterly unable to respond to their costs of living and law school debt. ${ }^{142}$ For attorneys paid a percentage of revenues, the work may slow to a trickle, but they remain engaged and in a position to rebound.

Clients, however, are less concerned about a law firm's retention issues than controlling costs and receiving value. An explanation of their philosophy was published in the ACC magazine. "In general, high-value, high-complexity matters should be handled by the most skilled resources, and low-value, low-complexity matters should be handled by lower-level, lower-cost resources." ${ }^{143}$ The recommendation highlights the expectation of inside counsel that work will be apportioned based on value, and a firm that can scale costs will be in a much stronger position than one that cannot.

The attitude regarding contract attorneys is often negative, both for the profession and for those who have the transitional employment. But as one

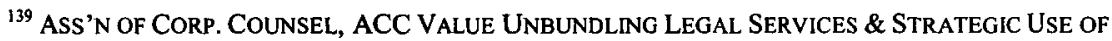
LAW FIRMS IN LOWER COST CITIES (2009), available at http://www.acc.com/advocacy/valuechallenge /toolkit/loader.cfm?csModule=security/getfile\&pageid=742186\&page=/legalresources/resource.cfm\&q string=show $=742186 \&$ title=Unbundling $\% 20$ Legal $\% 20$ Services $\% 20 \% 26 \% 20$ Strategic $\% 20$ Use $\% 20$ of $\%$ 20Law\%20Firms\%20in\%20Lower\%20Cost\%20Cities.

${ }^{140} I d$.

${ }^{141} \mathrm{Id}$.

${ }^{142}$ See Peter D. Zeughauser, Recession Resistant: Does Your Firm Have What It Takes to Survive the Next Big Downturn?, AM. LAW (May 1, 2007), http://www.law.northwestern.edu/career/markettren ds/2007/l rijtwd1.pdf ("When [the 1990s] recession hit, depressed profits and artless associate layoffs were the order of the day. Entire practice areas were purged of their associates.").

${ }^{143}$ Richard Rothberg \& Kevin Blodgett, First What, Then Who: Optimizing Workload Allocation \& Resource Management, ASS'N OF CORP. COUNSEL DOCKET, Oct. 2011, at 41, 46, available at http://secure.acca.com/advocacy/valuechallenge/toolkit/loader.cfm?csModule=security/getfile\&pageid $=1296928$ \&page=/legalresources/resource.cfm\&qstring=show $=1296928 \&$ title=First $\% 20$ What $\% 2 \mathrm{C} \% 2$ 0Then $\% 20$ Who\%3A\%200ptimizing\%20Workload\%20Allocation\%20and\%20Resource $\% 20 \mathrm{Managem}$ ent. 
such attorney noted, "[t]he popular perception is that contract attorneys are miserable drones hired by staffing firms to toil in the document review trenches generating billable hours in discovery by coding documents. On the contrary, the best contract attorneys have developed niche practices that offer law firms cost-effective assistance." 144

On the scale of engagement, of counsel attorneys maintain an ongoing relationship between the lawyer and the firm while the contract attorney may be more temporary, carrying his or her skill set from employer to employer. At the bottom of the engagement pyramid is the practice of legal process outsourcing ("LPO"), often characterized as utilizing Indian lawyers. ${ }^{145}$ "One popular-and often controversial-method law firms have used to maintain the bottom line is to pass legal work to other countries through legal process outsourcing ...."146 Whatever the benefits and drawbacks to outsourcing on U.S. lawyers, it is an increasing expectation of clients that work which can be done by an overseas attorney for a fraction of the cost of an attorney, a contract attorney, or a paralegal be provided by that low-cost provider. ${ }^{[47}$

Work done by attorneys or paralegals that is too complex for their training (or too rushed to be done properly) will result in shoddy work and possibly malpractice. The scalable law firm will also have sophisticated human resources management capability and careful quality control systems in place. Managing scalability does not mean providing the cheapest possible solution. Rather, it requires a full understanding of the capability at every level of the value chain and careful supervision throughout that process. The firms that fully understand scalability will engage their various personnel to assure that appropriate work is being assigned and supervised.

${ }^{144}$ Carol A. Fritz, Contract Attorneys, PHILA. LAW., Spring 2009, at 6.

145 See Sejal Patel, Is Legal Outsourcing Up to the Bar? A Reevaluation of Current Legal Outsourcing Regulation, 35 J. LEGAL PROF. 81, 81-82 (2010) (describing a process of passing legal work to other countries such as India).

${ }^{146} \mathrm{Id}$. at 81 . "By using LPOs, law firms can acquire services for $30 \%-70 \%$ less than what they would pay in the U.S., according to the Associated Chambers of Commerce and Industry of India. LPO salaries for Indian lawyers are generally below $\$ 10,000$ a year; by comparison, a U.S. contract lawyer usually earns around $\$ 30$ an hour and associate base salaries at major firms in New York start at $\$ 160,000$ a year." Id. at 82 (footnote omitted).

147 See Jack A. Guttenberg, Practicing Law in the Twenty-First Century in a Twentieth (Nineteenth) Century Straightjacket: Something Has to Give, 2012 MICH. ST. L. REV. 415, 445 (2012) ("Clients have come to realize that legal services can be decomposed into constituent parts, unbundled, and serviced by different providers. This permits those directing the provision of services, whether it is the client or the lawyer, to send various aspects of the work to the least costly, most efficient provider."); Robertson, supra note 23, at 135-37 ("Legal process outsourcing results in monetary savings for the law firms and companies who engage in it. . . [1]t is corporations in need of legal services ... that so far have taken the lead in sending work offshore."). 


\section{G. Profitable}

Being profitable is essential for the lawyer to stay in business and to justify providing the kind of services one wishes to deliver. ${ }^{148}$ At the same time, for a firm to be effective and efficient, it must seek to be optimally profitable rather than to maximize profits. ${ }^{149}$ For example, intellectual property boutique firms often do better outside Big Law practice settings because the flat rates for patent prosecutions do not match the hourly rates for other services. ${ }^{150}$ One aspect of profitability emphasizes the specialization discussed above.

Focus on profitability. Fifteen years ago, it was a cardinal sin to measure profitability at the practice group level. . . . Today, most firms are beginning to use software to determine profitability at the practice group level, and they are moving toward measuring it at the client, engagement, and individual-lawyer level. . . . This focus on profitability has led to great financial strength, allowing many firms to make long-term investments and reduce their reliance on debt. Both have made them stronger going into the next recession. ${ }^{151}$

As suggested, the software can provide the metrics for measuring profitability. The role of technology also serves as a leveler between small firms and Big Law firms. The networked lawyer can operate as efficiently in either setting. Through computer tools for research, document management, calendaring, and outsourced human resource functions, a small firm can operate as efficiently as a larger one. ${ }^{152}$ In fact, small firms

${ }^{148}$ Only with profitability can an attorney be free not to bill. See Desiree A. Johnson, Starting Strong, 93 A.B.A. J. 26, 71 (2007) ("When I focus on caring for my clients and providing them what they need, regardless of what I can bill them, things work out for both of us.").

149 See Stephanie Francis Ward, Virtually Practicing, 95 A.B.A. J. 50, $52-53$ (2009) (reducing overhead costs at a firm results in a greater percentage of revenue retained as profit).

${ }^{150}$ See Rachel M. Zahorsky, IP Does Not Mean Insane Profit, 95 A.B.A. J. 33, 34 (2009) ("“At a large firm where billing rates are high and you are required to bill by the hour, you can't charge your standard rates for the work,' [one attorney] explains. 'If you charge $\$ 400$ an hour or $\$ 500$ for an experienced attorney, then you are looking at 10 hours of your time. It's very hard to draft an entire 20- to 25-page patent application in 10 hours."').

151 Zeughauser, supra note 142.

${ }^{152}$ See, e.g., Aviva Cuyler \& Lance G. Godard, Finding Technology that Fits, How Five Law Firms Put It All Together, 28 GPSOLo 20 (2011) ("With an Internet connection and a laptop, lawyers have access to the tools, client data, and virtually all of the information they need to service clients, from anywhere in the world, using technology that only a few years ago was out of reach to all but the biggest firms."); Wanda J. R. Nuxoll, Virtually Turbocharged, 28 GPSOLO 32 (2011) (discussing use of virtual offices for solo and small firm practitioners); Richard S. Granat \& Marc Lauritsen, The Next; Five Years: Predictions for the Future of ELawyering, ABA L. PRAC., Sept.-Oct. 2011 at 42, 42-43 (discussing adoption of client portals, interactive document assembly, and other tools for the solo and small practitioner). 
"may be far more efficient without the big company and all the inefficiencies and stumbling blocks that its bureaucracy and 'technostructure' tend to produce.,"153

But technology is not the primary focus on a shift from revenue to profitability. The key to understanding long-term profitability is assuring that the right mix of activities creates a sustainable revenue model. "The point of running a law firm is to create an entity, machine, or investment that will continue to bear optimally leveraged rewards for the longest period of time."154

Time is a critical component of profitability. As such, profitability should not be conflated with greed. "[T]he priority on short-term profits undermines moral values and social responsibilities." 155 Prioritizing shortterm profits does not optimize a firm's sustainable profitability, ${ }^{156}$ and a well-run firm should manage to avoid such short-cuts-both from the moral standpoint and from an economic one. In contrast, " $[\mathrm{g}] \mathrm{reed} . .$. is surely responsible for much of the bar's complicity in financial, environmental, and health and safety disasters." 157

Sometimes described as "continuous renewal," the healthy management model calls for an ongoing balance of a firm's "existing strengths and opportunities while simultaneously pushing it to explore new opportunities and capabilities that will be needed for competing successfully in the future."158 The continuous renewal model requires a constant assessment of what is profitable, what is emerging, and what must change soon. ${ }^{159}$ While this may be difficult for law firms with an established cadre of senior partners unwilling to forego large partnership draws, their value proposition should be addressed as rigorously as the junior associates. Each person at the firm should be accountable for adding to both profitability and long-term capacity. ${ }^{160}$ If senior partners

${ }^{153}$ Glenn Harlan Reynolds, Small Is the New Biglaw: Some Thoughts on Technology, Economics, and the Practice of Law, 38 HoFSTRA L. REV. 1, 5 (2009).

${ }^{154}$ Carolyn Thornlow, Exercising Leadership: The Benefits of Management Training in Small and Midsize Law Firms, LAW FIRM MGMT. 11 (2008).

155 Deborah Rhode, Profits and Professionalism, 33 FordHAM URB. L.J. 49, 49 (2005) [hereinafter Rhode, Profits and Professionalism].

${ }^{156}$ See AlM Legal Intelligence, Thinking Like Your Client: Strategic PlanNing IN LAW FIRMS 9 (Oct. 2012) (discussing the failure to use aggregate profitability as the measure of success and concominant failure to "put fewer resources (such as new associates or marketing spend) in some of the less-profitable areas").

${ }^{157}$ Rhode, Profits and Professionalism, supra note 155, at 50.

${ }^{158}$ Bala ChakraVarthy \& PETER LoRANGE, Profit OR GrowTH?: WhY YOU DON'T HaVE to CHOOSE 14 (2007) (describing the "tension between ensuring profitable growth today and sustaining profitability and growth over the long run").

${ }^{159}$ See id. at 55 ("The firm is transformed over time but through a sustained sequence of leverage (leading to build) and build (leading to leverage) strategies.").

${ }^{160}$ See Zeughauser, supra note 142 (questioning the trend of firms adopting multitier partnerships where nonequity partners' compensation harms profitability). 
are entitled to reduce their billable hours, then they should at least be making up their value through brand enhancement and public engagement.

The remaining three attributes, while not absolutely necessary for the successful firm of the future, still align both the goals of the lawyer and the goals of the profession. In this way, these goals enhance a firm's health and sustainability.

\section{H. Socially Responsible and Civically Engaged}

Ironically, social responsibility and civic engagement are consistent with sustainable, optimal profitability. Profitable, successful firms have the resources to invest in civic engagement and understand that the time spent is a long-term strategic investment rather than a mere ancillary activity.

For example, a firm focused on its long-term success needs to cultivate trust and demonstrate effectiveness in a wide variety of settings. Pro bono efforts that provide both direct legal services and opportunities to develop legal skills without regard to billing obligations benefit the firm as much as the clients who are served. Civic engagement and bar leadership provide critical professional rewards that assist lawyers who may not otherwise receive esteem from the sophistication of their clients or of their legal work. ${ }^{161}$ Although the empirical data suggests that lawyers "do not assign prestige to work that is more oriented to the public good than profit,"162 acting in the public good in the civic arena brings with it benefits to society while bringing lawyers of all levels into professional relationships with lawyers and potential clients from strata that may not otherwise be easily approachable.

For some attorneys, social responsibility and civic engagement are a purpose and end in themselves. ${ }^{163}$ For others, however, who need to see the time and effort as supportive of the firm's endeavors rather than a distraction from it, such activities provide important training and cultivation opportunities for the lawyers and expand the firm's ability to build relations of trust with potential clients. ${ }^{164}$ As noted earlier, this may

161 HEINZ ET AL., supra note 114, at 81-83, 97 (noting that a lawyer's prestige comes from a variety of factors that correlate with income, sophistication of work, autonomy, and association with prestigious clients).

${ }^{162}$ Id. at 88-89.

${ }^{163}$ Deborah L. Rhode, Senior Lawyers Serving Public Interests: Pro Bono and Second-Stage Careers, ABA PROF. LAW., 2011, at 1 ("People are happiest when they feel they are being effective, exercising strengths and virtues, and contributing to socially valuable ends."); see also W. Taylor Reveley III, The Citizen Lawyer, S0 WM. \& MARY L. REV. 1309, 1316 (2008) ("[T] reasons for us to be citizen lawyers: first, for our own professional happiness and satisfaction; ...")

164 Rhode, Profits and Professionalism, supra note 155, at 58 ("Through pro bono programs, lawyers can develop new areas of expertise and demonstrate marketable skills. Participation in community groups, charitable organizations, high visibility litigation, and other public interest 
create a particularly effective role for senior partners who have strong professional reputations but no longer have as much capacity to bill as productively as they once did.

\section{Exemplifying Work-Life Balance and Cultural Sensitivity}

Boundaries between personal life and professional life are difficult to manage for practicing lawyers, and technology has not helped. Work can no longer be left at the office. Attorneys can be phoned, texted, emailed, friended and pinged anywhere in the world at almost any time. Moreover, if the attorney works from home, there are no physical separations between work and personal life. So the boundaries set by the firm (or by the individual, solo practitioner) must be put in place as a conscious, planned effort to protect the lives of the attorneys and the values of the firm.

This attribute of the optimal firm is squarely at odds with the management of Big Law and short-term profit maximization. But to see the pattern, one need only ask why firms chose to pay starting associates absurd initial salaries ${ }^{165}$ when they could have easily increased the number of associates for the same cost and billed those associates at a higher cumulative profit. ${ }^{166}$ Explicitly optimizing work-life balance reinforces the value proposition of sustainable profitability rather than short-term reward as well. ${ }^{167}$

A corollary of work-life balance is sensitivity to disparate treatment or discriminatory outcomes in the practice of law. Big Law firms tend to be dominated by white males. ${ }^{168}$ "Women and men report being treated

activities allows attorneys to expand their perspectives, enhance their reputations, and attract paying clients.").

${ }^{165}$ Burk \& McGowan, supra note 23, at 20-21, 25 (2011) ("Ironically, as salaries and billing rates rose steeply, elite firms hired more law graduates with fewer of the traditional qualifications the firms claimed to value. And those graduates received increasingly higher salaries to spend increasingly long hours performing monotonous and menial tasks organizing large quantities of information and documents.").

${ }^{166}$ Instead of hiring an associate at $\$ 160,000$ per annum to bill 2,000 hours, a firm could spend $\$ 75,000$ per associate to bill 1,200 hours. The $\$ 10,000$ savings and 400 additional billable hours would more than offset the overhead; the 200-500 hours of free time could be used for training; and the associate would be far more satisfied and more likely to stay at the firm in good economic times. Of course, some associates choose greed and short-term reward as well, but should a firm value the associates who want to opt into such a system? Moreover, the lure of these "jackpot" salaries may have fueled some of the unsustainable increases in law school tuition. Orin Kerr, What Drives Law School Tuition?, VOLOKH CONSPIRACY (Aug. 17, 2011 7:13 PM), http://www.volokh.com/2011/08/17/whatdrives-law-school-tuition/ ("My sense is that the high salaries offered to associates at big law firms have made many students less sensitive to debt than they otherwise would be, which has in turn lessened pressure on schools to limit tuition hikes.").

${ }^{167}$ See, e.g., Johnson, supra note 148, at 26 (discussing the ability to work in jeans and flip-flops as well as having the time and ability to meet with her clients at their nursing homes to gain trust).

${ }^{168}$ HEINZ ET AL., supra note 114, at 151-52 ("[L]aw schools and the organized bar erected formal barriers to exclude blacks and women. . . As late as 1971 , only 3 percent of lawyers were women. .. . 
differently by colleagues and employers, who are (still) mostly men."169 This results in different standards for promotion, denial of assignments with important clients, and less prominent positions of senior management. ${ }^{170}$ "Like women, black lawyers may be less likely to be given the challenging assignments that both lead to the development of important legal skills and provide young professionals with opportunities to impress the partners evaluating them."

To the extent that technologically mediated metrics can provide meaningful assessment tools on productivity and effectiveness, such tools should be able to provide some methods for assigning work and evaluating work that has fewer intentional or implicit biases. To the extent virtual law firms and disaggregated law firm structures rely more heavily on attorney initiative and less on a hierarchical partnership control mechanism, these structures should ameliorate the differential treatment caused by bias. ${ }^{172}$

Ultimately both the work-life balance issue and the disparate treatment issue are aspects of the same management ineptitude. Law firms, typically managed by lawyers who have never received any formal education on management, ${ }^{173}$ recognize that these corrosive situations exist; ${ }^{174}$ that they suffer high rates of attrition; ${ }^{175}$ and that there is little firm loyalty at least in part because the firm never engendered any loyalty to its attorneys. ${ }^{176}$ Yet

A quarter of a century later, in the 1997-1998 school year, people of color received somewhat more than a fifth of all law degrees....").

${ }^{169}$ Id, at 153; see also Marc Galanter \& William Henderson, The Elastic Tournament: A Second Transformation of the Big Law Firm, 60 STAN. L. REV. 1867, 1913-21 (2008) (discussing the disparate effects of associate mentoring on women and minorities).

${ }^{170}$ HEINZ ET AL., supra note 114 , at 153-54, 158.

${ }^{171}$ Id. at 154

172 There are correlations other than with bias against women and attorneys of color that affect professional success. For example, lawyers who begin in government work tend to have lower salaries and generally do not achieve the same levels of financial success or firm management as those who start their careers in firms or in-house. More entrants into government jobs are women or lawyers of color than white males. This is attributed both to applicant preference and to steering by the applicant's mentors and potential employers. See generally id. at 153 (illustrating such correlation).

${ }^{173}$ Elizabeth Chambliss, New Sources of Managerial Authority in Large Law Firms, 22 GEO. J. LEGAL ETHICS 63, 65-66 (2009) (discussing a new model of professional management for large firms and the resistance to such leadership).

${ }^{174} \mathrm{Id}$. at 77 ("Most commentators acknowledge the increasing demand for dedicated executive management in large law firms.").

${ }^{175}$ See, e.g., Courtney Goldstein, Professional Development: The Expanding Scope of Lawyer Training Programs, A.B.A. LAW PRAC., Apr.-May 2008, at 48, 49 ("The National Association for Law Placement (NALP) reports that 78 percent of new lawyers leave large firms by the time they are in their fifth year. Since it costs between $\$ 250,000$ and $\$ 500,000$ to replace an associate, this quickly becomes a multimillion-dollar problem.”).

${ }^{176}$ See id. ("Today's young lawyers do not expect to work at the same firm (or even necessarily remain lawyers) for the rest of their lives."). See generally Eli Wald, A Primer on Diversity, Discrimination, and Equality in the Legal Profession or Who Is Responsible for Pursuing Diversity and Why, 24 GEO. J. LEGAL ETHICS 1079 (2011) (reviewing various reasons for disparate impact on women and minority caused by financial incentives, lack of mentoring, and other management decisions). 
recognizing these failings, most law firms shrug collectively and continue to operate under the same sweatshop model in search of larger per-partner revenues. $^{177}$

\section{J. Valued Intermediaries Providing Highly Personalized Consultative Advice}

At the heart of great lawyering and the nobility of the profession is the counselor's role advising clients and championing their causes. The best firms will seek to excel in this metric, taking pride in their reputation rather than their size. As Richard Susskind notes, "because of the nature of some legal work, there will always be a place for bespoke work." ${ }^{178}$ The place that provides bespoke, individualized work will remain as the most prestigious and profitable of the practice.

Even though the demand for tailored specialty work will lessen over time, the increasing complexity of the globalized world will produce new novel issues to keep up demand. Someone has to provide this advice and representation. There is no reason to believe that the behemoth Big Law firms will be more attractive to clients than more streamlined, efficient, and technologically engaged firms. ${ }^{179}$

The most successful firms will employ what has been termed the "reintermediation" strategy to build value for its clients in every interaction, so that the client comes to rely on the law firm and pay a premium for his or her trust in its brand. ${ }^{180}$ The strategy of becoming a trusted brand has been exemplified by Amazon.com and Apple, and applies equally well to the law firm. ${ }^{181}$

Since a law firm cannot require an exclusive relationship with a client, ${ }^{182}$ the best it can hope for is that the services it provides will be too

${ }^{177}$ See Galanter \& Henderson, supra note 169, at 1903-04 (noting that "[f]or decades, virtually all large law firms have operated under some variant of the [same system]," where from 1998-2008 "the average profits per equity partner among the most profitable quartile of firms (ranked 1-50) has increased $95.3 \%$, from $\$ 926,571$ to $\$ 1,809,935 ")$; Alex M. Johnson, Jr., Think Like a Lawyer, Work Like a Machine: The Dissonance Between Law School and Law Practice, 64 S. CAL. L. REV. 1231, 1251 (1991) ("[L]aw firms have been forced to focus on profit, with the result that associates must work more and more hours on projects that a few years ago the firm perhaps would not have accepted or would have given to a paralegal.").

${ }^{178}$ SUSSKIND, supra note 24 , at 39.

179 Burk \& McGowan, supra note 23, at 86, 101.

180 See Jon M. Garon, Reintermediation, 2 INT'L J. PRIVATE LAW, 227, 231 (2009) ("Reintermediation strategy utilises contracting strategies, consumer data information and structural business approaches to encourage additional steps in the consumer transaction which build an ongoing relationship between the enterprise and the consumer.").

${ }^{181} I$ d.

${ }^{182}$ MODEL RULES OF PROF'L CONDUCT R. $1.16 \mathrm{cmt} .4$ (2011) ("A client has a right to discharge a lawyer at any time, with or without cause, subject to liability for payment for the lawyer's services.").

[A] client has the absolute right to discharge the attomey and terminate the relation 
beneficial for a client to switch. While price is one variable, it is not the only one. Quality control, relevance of the work product, responsiveness, and trust all play significant roles in the value proposition for the client.

The brand must be trustworthy for the client to entrust any specialty or bespoke work. At a minimum, brand strength will justify a client's willingness to contract with a firm. "[F]irm reputation apparently matters to the extent that in-house counsel do not want to be second-guessed for giving an important matter to counsel that no one in senior management or on the board has heard of." ${ }^{\prime 183}$ A less flattering view of this relationship is that senior management wants the "cover" of hiring a name-brand law firm, so that any later errors will be blamed on the law firm rather than on the decision to hire that particular law firm. Law firms are often sought out to essentially "bless" decisions that have already been made by management, so that the better the firm's reputation, the more potent the firm's blessing on the outcomes. ${ }^{184}$

Similarly, the workforce of the law firm must meet the expectations of the client. "Many major corporate purchasers of legal services now explicitly require their law firms to show a commitment to diversity and some, including Wal-Mart, have withdrawn work from firms who failed to live up to diversity standards." ${ }^{185}$ This highlights that the work-life balance

at any time, even without cause. A client's discharge of his attorney is not a breach of the contract of employment but the exercise of his right. This right to terminate is a term of the contract implied by public policy because of the peculiar relationship between attorney and client.

AFLAC, Inc. v. Williams, 444 S.E.2d 314, 316 (1994) (citations omitted) (internal quotation marks omitted).

${ }^{183}$ Burk \& McGowan, supra note 23, at 65-66 ("Just as no one ever got fired for buying IBM (at least once upon a time), no one is going to second-guess an in-house lawyer for hiring, say, Skadden on a matter of consequence.").

${ }^{184}$ Thomas G. Bost, Corporate Lawyers After the Big Quake: The Conceptual Fault Line in the Professional Duty of Confidentiality, 19 GEO. J. LEGAL ETHICS 1089, 1100 (2006).

\begin{abstract}
A very real possibility is that Enron management wanted its sophisticated and trusted legal counsel to issue a report on its prestigious letterhead that had the appearance (but not the reality, if closely and discerningly read) of blessing the SPE transactions. It may have desired a "protective document" from a credible source that would "provide cover on the broader question: There is no problem that deserves a full investigation." Its object may have been to use the V\&E report "to paint a gloss of respectability (sprinkle holy water, as it were) on dubious transactions."
\end{abstract}

Id. (quoting Roger C. Cramton, Enron and the Corporate Lawyer: A Primer on Legal and Ethical Issues, 58 BuS. LAw. 143, 164, 166 (2002) and Jeffrey N. Gordon, Governance Failures of the Enron Board and the New Information Order of Sarbanes-Oxley, 35 CONN. L. REV. 1125, 1201 (2003)); see also Susan P. Koniak, Corporate Fraud: See, Lawyers, 26 HARV. J.L. \& PUB. POL'Y 195 (2003) (describing the presence of lawyers in the realm of corporate scandals as "know[ing] no bounds").

${ }^{185}$ Douglas E. Brayley \& Eric S. Nguyen, Good Business: A Market-Based Argument for Law Firm Diversity, 34 J. LeGAL PROF. 1, 10 (2009). 
and cultural sensitivity of the firm serve as prerequisites to engagement with clients sharing similar values. These values go to the core brand proposition of the firm.

Strong brands attract not only strong clients, but also strong employees. The virtuous cycle of creating effective recruiting cultures will enhance the ability to provide the kind of premium work sought by premium clients.

Strong brands are focused on the value proposition they provide to their clients. As such, the metrics for value, specialization, and the emphasis on long-term optimization and fee structures that create incentive for long-term successful relationships will all build the brand. Apple, for example, does not possess the majority of market-share in any product category (other than tablet computers, and only for a short time). ${ }^{186}$ Nonetheless, the high-quality value proposition it provides to its customer allows it to command a strong price premium over its competitors in each of its product categories. Amazon.com, by contrast, competes in terms of both price and volume. ${ }^{187}$ It uses its interface to predict what the customer will need next, so it is ready for that customer demand as it arises. ${ }^{188}$ Its software promotes some additional purchases, but more importantly, it precludes third parties from obtaining a foothold in the customer relationship. ${ }^{189}$

The best law firms will adopt these two strategies. They will understand the needs of their clients and provide information in anticipation of the client's needs. Much of this information will be systematized or packaged, so the cost will not be great for the firm or the client, but its timeliness will engender a premium and the delivery will enhance the relationship. This means that summary information for clients will be written in a form useful to the client, not based on the format preferred by the firm or a court. Lawyers will even employ charts and color, when effective, to communicate, and use in-house videos to train clients' personnel.

Firms will learn what not to bill for, enabling the firm to strengthen the relationship with its clients. Done right, the firm will still be charging fees

186 See Dan Graziano, Apple's Tablet Share Slides in Q4 Following Kindle Fire Launch, BGR.COM (Mar. 13, 2012), http://www.bgr.com/2012/03/13/apples-tablet-share-slides-in-q4following-kindle-fire-launch/ (predicting "Android-based tablets . . . will overtake Apple[] in terms of worldwide market share by 2015 "; however, iOS will remain market leader in terms of revenue (citing International Data Corporation Worldwide Quarterly Media Tablet and eReader Tracker)).

${ }^{187}$ See id. (describing the $\$ 199$ Kindle Fire's penetration in the tablet market, as well as Amazon's second place finish in the total number of Apple products sold and delivered).

${ }^{188}$ See Garon, Reintermediation, supra note 180, at 231 ("Most of the Amazon home page provides product recommendations based on the viewing history of the consumer.").

189 See id. at 232 ("Kindle's primary selling feature further reinforces the exclusivity of distribution sought by Amazon."). 
commensurate with the sophistication and skill of the marketplace. The firm will remain highly profitable and the client will recognize that the bill was fair and reasonable in light of the services provided. In these firms, the lawyers will be rewarded with good incomes, prestigious clients, and sophisticated work earning them the greatest prestige in the profession. ${ }^{190}$

Not all firms will follow this path. Many will choose to provide commodity services and make their money with volume and efficiency. Others will leverage the relatively poor knowledge members of the public have regarding the purchase of legal services and make a living with clients who are neither thrilled with their interaction with the law nor feeling disadvantaged. These firms will not rely on repeat business and will increasingly have to overcome tepid word-of-mouth reviews available in the public media. ${ }^{191}$

But for firms that match their client's brand value with that of the firm, provide excellence in service, promote efficiency in operations, and plan for long-term optimal value and profitability, the future of the legal practice remains as bright as ever.

\section{REINVENTING THE LAW SCHOOL FOR THE INFORMATION AGE}

Given the compelling evidence that law firms are changing and sophisticated small and medium firms have the potential to embrace technology in a way that will disrupt all facets of the profession, it seems logical that legal education must embrace change in order to meet these new demands. It may not be that simple.

\section{A. The Headwinds of Change}

The first challenge facing legal education is to catch up to the changes transforming the profession. In part, this question is another example of the tragedy of the commons, ${ }^{192}$ in that there are simply too many graduating lawyers for the number of jobs to be filled. The technological changes, outsourcing and other disruptions are significantly reducing the

\footnotetext{
${ }^{190}$ HEINZ ET AL., supra note 114 , at 90.

${ }^{191}$ Firms receiving strongly negative word-of-mouth will find it increasingly difficult to survive, as all but the least knowledgeable clients will shy away as will prospective employees. In addition, at some point the public information may trigger an automatic bar association ethics reviews based on the public knowledge that is imputable to the regulatory body.

${ }^{192}$ See, e.g., Irma S. Russell, A Common Tragedy: The Breach of Promises to Benefit the Public Commons and the Enforceability Problem, 11 TEX. WESLEYAN L. REV. 557, 557 (2005) (describing the problems associated with dying wetlands and its relation to the public interest); Dan Hunter, Cyberspace as Place and the Tragedy of the Digital Anticommons, 91 CAL. L. REV. 439, 509 (2003) (arguing that cyberspace is increasingly becoming a digital anticommons where inefficient use of resources is the norm); Garrett Hardin, The Tragedy of the Commons, 162 SCI. 1243, 1244-45 (1968) (delineating the pro-private property argument that resources become prone to overuse when too many individuals have rights to use the resource and no one can exclude any other).
} 
need for lawyers in a manner that is highlighted, but not actually caused, by the recession. The jobs will not necessarily return to the U.S. law firms when the market recovers. Instead, the cost savings provided by outsourcing and software will continue to be utilized.

Certainly, law schools cannot come together to restrict the number of seats available, ${ }^{193}$ so another approach is needed. In the absence of concerted and illegal activity, the willingness of some schools to restrict their capacity will only result in other law schools increasing capacity. States may heighten the scores needed to pass the state bar exam, but that solution leaves an increasing number of law school graduates without the ability to practice law and a debt they have little prospect in managing. ${ }^{194}$ In response, a small nonprofit named Law School Transparency ${ }^{195}$ has highlighted the J.D.-required job statistics and effectively advocated for better reporting of law school job statistics. The employment data and its economic implications have fueled a systemic decline in law school applicants. ${ }^{196}$ However, the size of the applicant pool will only require a reduction in class size when the pool shrinks so far that applicants are no longer qualified. The applicant pool size does not directly control the number of seats available for law school.

A second challenge is highlighted in the literature on disruptive innovation. The existing commitment to core customers and current operations makes it extremely difficult to embrace a change that might undermine core procedures to which an organization has been committed. "The very decision making and resource-allocation processes that are key to the success of established companies are the very processes that reject disruptive technologies: listening carefully to customers; tracking competitors' actions carefully; and investing resources to design and build higher-performance, higher-quality products that will yield greater profit.",197

The better-managed law school recognizes that it has multiple

${ }^{193}$ See United States v. ABA, 934 F. Supp. 435, 435 (D.D.C. 1996) (applying a consent decree prohibiting the $A B A$ from engaging in various anticompetitive activities related to law school accreditation); George B. Shepherd \& William G. Shepherd, Scholarly Restraints? ABA Accreditation and Legal Education, 19 CARDOZO L. REV. 2091, 2137 n.158 (1998) (discussing ABA consent decree).

${ }^{194}$ William D. Henderson \& Rachel M. Zahorsky, The Law School Bubble, A.B.A. J., Jan. 2012, at 32, 32 ("Heavy loans now threaten to consume the future earnings and livelihood of the nation's young lawyers. Yet, even as the legal market contracts, more than 87,900 potential candidates vied for 60,000 seats at $200 \mathrm{ABA}$-approved law schools in 2011, according to the Law School Admission Council.").

${ }^{195}$ About LST, LAW SCH. TRANSPARENCY, http://www.lawschooltransparency.com/about/ (last visited Jan. 3, 2013).

${ }^{196}$ See Jonathan D. Glater, In Lean Times for Law Schools, an Opportunity, N.Y. TIMES (Dec. S, 2012), http://dealbook.nytimes.com/2012/12/05/in-lean-times-for-law-schools-an-opportunity/ (noting law school applicant pool trends for the 2011-2012 school years).

${ }^{197}$ CHRISTENSEN, supra note 68 , at 98. 
customers: the students who attend; the practicing bar which utilizes (and sets the relative value for) the law school's diplomas; major donors who act more like large customers than shareholders (with similar attributes of control); and the school's university, which plays a role analogous to both the law school's parts supplier and its largest creditor. Both the bar and the students are direct customers; the other constituencies are key components of the law school's economic business model. ${ }^{198}$

When the law school's customers are juxtaposed against its entrenched management, ${ }^{199}$ the problem becomes clear. Legal education has been working for at least two decades to improve education. ${ }^{200}$ In all that time, however, faculty and administrations have focused on serving our existing customers better-sometimes just the students, sometimes just the bar and sometimes both-but rarely have law schools focused on preparing our students for the practice to come. ${ }^{201}$ The thoughtful work on improving the delivery of legal education has focused on the subjects we presently teach rather than questions about what skills should be used to further the business and profession of law.

The third challenge is that today's legal education may not be particularly good at serving even the customers we have. Dean Alex Johnson noted that the current legal education model really focuses on teaching students to behave much like law faculty, a set of skills that has little relevance outside the academy.

At best, elite law schools prepare their top five students to become law professors but fail to prepare the rest of their students to become practicing lawyers. Not only do they fail

${ }^{198}$ Despite what they might think, faculty members are not customers.

199 See Paul L. Caron \& Rafael Gely, What Law Schools Can Learn from Billy Beane and the Oakland Athletics, 82 TEX. L. REV. 1483, 1553 (2004) (reviewing MiCHAEL LEwIS, MONEYBALL: THE ART OF WINNING AN UNFAIR GAME (2003)) ("As [Groucho] Marx might say, the innovative law school of the future (like the Oakland A's of today) very well might be one which would never have hired its dean as a faculty member (or its general manager as a player) in the first place." (paraphrasing Grocho rather than Karl Marx)).

${ }^{200}$ See, e.g., Legal Education and Professional Development-An Educational Continuum, Report of the Task Force on Law Schools and the Profession: Narrowing the Gap, 1992 A.B.A. SEC. ON LEGAL EDUC. \& ADMISSIONS TO THE BAR 3 [hereinafter MACCRATE REPORT] ("Legal educators and practicing lawyers should stop viewing themselves as separated by a 'gap' and recognize that they are engaged in a common enterprise-the education and professional development of the members of a great profession."); ROY STUCKEY ET AL., BEST PRACTICES FOR LEGAL EDUCATION: A VISION AND A ROADMAP 1 (2007) [hereinafter BEST PRACTICES REPORT] ("[W]e hope to the document will facilitate dialogue about legal education among law teachers and between law teachers and other members of the legal profession."); WILliam M. SUllivan eT AL., EDUCATING LAWYERS: PREPARATION FOR THE PROFESSION OF LAW 1-4 (2007) [hereinafter CARNEGIE REPORT] ("[T] he focus of this book is on the preparation of lawyers, more particularly on their preparation in law school-the crucial portal to the practice of law.").

${ }^{201}$ See, e.g., BEST PRACTICES REPORT, supra note 200, at 39 (noting that today's law schools possess "multiple missions"). 
to educate their students in legal doctrine and rigorous analytical thinking beyond the first year, but they also fail to impart the proper state of mind for legal practice. Elite law school education contrasts starkly with the reality of practice, and students suffer as a result. In legal education we encourage students to explore the relationship between law and other academic disciplines, and then we send them out into the real world unable to practice a kind of law that rarely recognizes law's relationship to anything but money. We teach them to think like lawyers while they are students, but as junior associates they are treated like drones who must suppress their individuality and intelligence for the good of the firm's bottom line. The discordant emphases of legal education and actual practice are the root of the dissatisfaction that new lawyers experience. ${ }^{202}$

This is the gap that is best addressed by the skills, values, and goals espoused in the MacCrate Report and the Carnegie Report. While efforts have been made at elite and regional schools between the issuance of the two reports and in their aftermath, law school change occurs slowly.

The fourth challenge turns on the limitations of the MacCrate Report, which focuses on technical skills and professional values rather than the attributes that lawyers require to be successful. ${ }^{203}$ As Professor Nancy Rapoport notes, many attorneys are frustrated that other members of the bar cannot "play well with others." 204 These attributes are captured in the Carnegie Report as "attitude," 205 and are captured in the Best Practices Report in a number of its twelve competencies. ${ }^{206}$ Professor Rogelio Lasso has summarized this attitude as requiring "perspective (ability to consider the historical, political, ethical and moral aspects of a problem) [and] personal attributes (qualities of character that pertain to how lawyers go

202 Johnson, Jr., supra note 177, at 1252.

${ }^{203}$ See John Burwell Garvey \& Anne F. Zinkin, Making Law Students Client-Ready: A New Model in Legal Education, 1 DUKE FORUM FOR L. \& SOC. CHANGE 101, 119-21 (2009) (discussing the Daniel Webster Scholar Honors Program for competency-based admission to the bar).

${ }^{204}$ Nancy B. Rapoport, Changing the Modal Law School: Rethinking U.S. Legal Education in (Most) Schools, 116 PENN ST. L. REV. 1119,1120 (2012) [hereinafter Rapoport, Changing the Modal Law School]; see also John O. Mudd, Beyond Rationalization: Performance-Referenced Legal Education, 36 J. LEGAL EDUC. 189, 198 (1986) (describing this attribute as "perspective").

${ }^{205}$ CARNEGIE REPORT, supra note 200, at 22 (discussing imperative to "[p]roved[e] students with the capacity to engage in complex practice" and "enabl[e] students to learn to make judgments under conditions of uncertainty"); see also Mudd, supra note 204, at 197 (describing this attribute as "perspective").

206 BEST PRACTICES REPORT, supra note 200, at 54 (listing "Use risk management skills;" "Manage their personal workload and manage efficiently and concurrently a number of client matters;" and "Work as part of a team," as examples). 
about their professional activities and the ways they relate to others)."207 The personal attributes correlate with successful law practice but not with either the LSAT or the Bar exam, so there is a fundamental disconnect between what those law schools seek, what they test, and what the profession hopes to achieve. ${ }^{208}$ Without closing the attributes gap, other reforms may continue to produce a different, but still unsatisfied and unsuccessful contingent of alumni in each class. ${ }^{209}$

The fifth challenge is a fear that even if law schools were to accept the winds of change that are blowing through the legal profession, the nature of that change will be hard to predict and it would be foolhardy to base a curriculum on it. Professor Ward Coe points out that law firms are highly varied, unlikely to provide good information on their culture and operations, and "belie any productive attempt at generalization." $210 \mathrm{He}$ suggests, "it would be difficult to provide students with generally applicable, useful, and practical information. Instead of attempting to do so, law schools should continue to focus on legal analysis and writing and to encourage application of these skills through clinical courses."211

There is some key wisdom in Professor Coe's suggestion. All lawyers engage in legal analysis and writing; it is essential to everything a lawyer does. Written communication becomes even more important when a lawyer reduces the time spent directly in contact with his or her client. Similarly, skills-based courses introduce a number of the important skills that are typically missing from the doctrinal courses. Learning interviewing and counseling techniques, developing an understanding of a client's actual motivations, and managing actual case files are universally applicable for all law graduates.

At the same time, a live-client clinic still offers a more rarified experience than a field placement in a law firm. Clinical settings remain artificial, unburdened by billable hours, cost limitations, client competition or other pressures discussed throughout this Article. The accurate characterization that no exposure to the actual practice of law will be fully comprehensive should not stifle efforts to provide a reasonably good picture of the practice. The comment reflects the greatest challenge facing

${ }^{207}$ Catherine L. Carpenter et al., Report of the Outcome Measures Committee, 2008 A.B.A. SEC. OF LEGAL EDUC. \& ADMISSIONS TO THE BAR 7 [hereinafter Outcome Measures Report].

${ }^{208}$ See Marjorie M. Shultz \& Sheldon Zedeck, Predicting Lawyer Effectiveness: Broadening the Basis for Law School Admission Decisions, 36 LAW \& SOC. INQUIRY 620, 630 (2011) (identifying twenty-six attributes for professional success).

${ }^{209}$ See ROBERT KEGAN \& LISA LASKOW LAHEY, IMMUNITY TO CHANGE 98-99 (2009) (discussing the inability of a professional services firm-presumably a law firm-incapable of change because of its culture of individual autonomy, personal control and lack of commitment to a common agenda).

${ }^{210}$ Coe, supra note 25 , at 372.

${ }^{211}$ Id. 
law schools. Current efforts at change will be thwarted either by the inherent unknowable nature of the future or the incrementalist approach taken in most curriculum reform.

Despite these challenges, legal educators must press for change from inside before it comes from the outside. Put simply, legal education must change or die. With too many seats, too high a cost, and too little relevance to the profession into which schools are sending their graduates, the time has come for change. Admittedly, change is hard. If law schools choose to cling to existing business models, many of them will follow safe corporations like Polaroid, Kodak, Blockbuster, and Borders into irrelevance.

The threat, of course, is not the same at all law schools. Elite schools have a legacy of good will that will last generations. Law schools that primarily place their students into academia, into Big Law, or into Fortune 100 companies are less likely to feel the impact. But such schools do not represent a majority of the law schools, nor do such positions represent the majority of students-even at many of the elite law schools. For the rest, the time for change has been a long time coming.

The predictions of law firm practice remain to be seen. Similarly, the particular skills and values suggested will need to be empirically evaluated on an ongoing basis. As such, this Article does not advocate the same curricular change for each school. Instead, it suggests a process to ask the questions regarding what each law school's particular graduates will be doing in ten years and focusing on the skills and values graduates need in practice. Within the law school, moreover, there should be opportunity for students to self-select areas of interest and the appropriate skills associated with each area.

The answers will come by empirically observing what the graduates are actually doing rather than relying on what they are self-reporting. This is another lesson of managing disruptive innovation. "You have to be careful which customers you listen to, and then to watch what they do, not listen to what they say. . . . You've got to find a new set of customers, listen to them and follow them. Your current customers hold you captive to their needs."212 For example, a law school should not rely on alumni boards or other groups of self-identified populations for suggestions or guidance, since those people have a unique disposition toward the law school--highly biased in comparison to the profession and even biased with regard to the alumni population.

The remaining sections of this Article will attempt to sketch what this might look like for the technologically mediated law firm of the future.

${ }^{212}$ Clayton Christensen, Disnuptive Innovation-Dilemmas Persist, LEADERSHIP EXCELLENCE Sept. 2007, at 7 . 


\section{B. Retaining the Core of the Curriculum}

Given what may appear to be somewhat radical assumptions about the future of the profession, it may come as a surprise that the core curriculum of the first year legal education should remain largely the same, with only a few adaptations to reincorporate what has been left behind. This is essential because the primary output of law schools is still lawyers. ${ }^{213}$

This role of law schools as gatekeepers to the courthouse, ${ }^{214}$ and by extension, to the rule of law remains central to legal education. The skills and values described in the MacCrate Report remain fundámental to most practices of law and the values of the profession. ${ }^{215}$ "While legal education still has many improvements it can make, there is no doubt that the MacCrate Report has received high marks in the academy.,216 As such, there is little value in suggesting these fundamentals be replaced, though they do need to be augmented.

Most law schools require the subject matter courses of Torts, Contracts, Property, Civil Procedure, Criminal Law, Constitutional Law, and Legal Ethics, with most of those comprising the bulk, if not the whole of the first year curriculum. ${ }^{217}$ The subject matter correlates quite closely

213 See Alfred Z. Reed, Carnegie Foundation for the Advancement of Teaching, TRAINING FOR THE PUBLIC PROFESSION OF THE LAW 3 (1921).

Practicing lawyers ... are part of the governing mechanism of the state. Their functions are in a broad sense political .... [P]rivate individuals cannot secure justice without the aid of a special professional order to represent and to advise them. To this end lawyers were instituted, as a body of public servants, essential for the maintenance of private rights.

Id.

${ }^{214}$ Even this monopoly is shrinking as legal disputes adjudicated in courtrooms are declining while adjudication in arbitrations and other extra-legal fora are on the rise. Galanter, supra note 96, at 514-15.

${ }^{215}$ MACCRATE REPORT, supra note 200, at 138-41; Gerard J. Clark, Book Review, 27 SUFFOLK U. L. REV. 1153, 1155 (1993) (reviewing REPORT OF THE TASK FORCE ON LAW SCHOOLS AND THE Profession: NARROWING THE GAP BY THE AMERICAN BAR ASSOCIATION SECTION OF LEGAL EDUCATION AND ADMISSIONS TO THE BAR (1992)).

${ }^{216}$ Richard A. Matasar, Skills and Values Education: Debate About the Continuum Continues, 22 N.Y. L. SCH. J. INT'L \& COMP. L. 25, 27 (2003).

The ten fundamental skills set forth in the [Statement of Skills and Values] are: (1) problem solving, (2) legal analysis and reasoning, (3) legal research, (4) factual investigation, (5) communication, (6) counseling, (7) negotiation, (8) litigation and alternative dispute-resolution procedures, (9) organization and management of legal work, and (10) recognizing and resolving ethical dilemmas. The four fundamental values are: (1) provision of competent representation, (2) striving to promote justice, fairness, and morality, (3) striving to improve the profession, and (4) professional self-development.

Id. at 29-30 (citing MACCRATE REPORT, supra note 200, at 121-22).

${ }^{217}$ First Year Courses, LAW PREVIEW, http://www.lawpreview.com/index.php/FirstYearCourses/ (last visited Feb. 24, 2013). 
with the Multistate Bar Examination ("MBE"), a "six-hour, 200-question multiple-choice examination covering Constitutional Law, Contracts, Criminal Law and Procedure, Evidence, Real Property, and Torts."

Legal education unfortunately conflates the teaching of the first-year subjects with the fundamental legal skills for critical thinking and legal reasoning. There may be widespread consensus that "[t]he first year curriculum is supposed to overcome the fact that incoming students have weak analytical skills and to teach them to 'think like a lawyer'."219 Nonetheless, there is nothing inherent in the first-year subjects to suggest that the skill of legal analysis is taught through these courses. Faculty members use these topics to explore law and economics theory, social justice theory, and a host of interesting doctrinal approaches. ${ }^{220}$ The casebooks and materials provided to the students in these MBE-tested courses do not include any formal training on logic or reason. ${ }^{221}$

If, however, the first year is intended to focus on the MacCrate skill of analytical reasoning, colloquially referred to as thinking like a lawyer, then perhaps less time could be allocated to various subject matter and more time can be allocated to the detailed identification and teaching of the particular skill. In this way, a course ${ }^{222}$ on Logic would be provided in the first-year curriculum. ${ }^{223}$ Similarly, the implicit education on the role of the lawyer and the role of law on society would become a discrete course of study so students understand the profession they are entering and the roles they are expected to play.

If analytical reasoning is taught as a foundational skill, the credits allocated to a particular course can then become much more flexible. By

${ }^{218}$ Multistate Tests, NAT'L COMM'N BAR EXAM'R, http:/www.ncbex.org/multistate-tests/ (last visited Mar. 18, 2012).

${ }^{219}$ Robert M. Lloyd, Hard Law Firms and Soft Law Schools, 83 N.C. L. REV. 667, 681 (2005) (citing James R.P. Ogloff et al., More than "Learning to Think Like a Lawyer": The Empirical Research on Legal Education, 34 CREIGHTON L. REV. 73, 227 (2000)).

${ }^{220}$ See Nancy B. Rapoport, Eating Our Cake and Having It, Too: Why Real Change Is So Difficult in Law Schools, 81 IND. L.J. 359, 372-73 (2006) (discussing the motivation and rewards for faculty engagement).

${ }^{221}$ Ruggero J. Aldisert et al., Logic for Law Students: How to Think Like a Lawyer, 69 U. PITT. L. REV. 1,2 (2007) ("Notwithstanding the emphasis on logical reasoning in the legal profession, our law schools do not give students an orientation in the principles of logic.").

${ }^{222}$ I use the term "course," but this could be provided in modules, self-directed learning exercises, or any number of different modalities. The same applies to the traditional subject matter of courses described herein.

${ }^{223}$ Similarly, a course on Rhetoric (which may well be provided in conjunction with Logic) is appropriate to be added. In the historical, Langdellian golden-age of Kingsfield's law school, students were expected to recite by standing and engaging with the faculty in careful Socratic debate. Ian Gallacher, Thinking Like Non-Lawyers: Why Empathy Is a Core Lawyering Skill and Why Legal Education Should Change to Reflect Its Importance, ALWD, Fall 2011, at 109, 113-14, available at http://www.alwd.org/LC\&R/Currentlssues/2011/pdfs/gallacher.pdf. Whether this taught actual rhetoric is unclear, but the connection between logic, analysis, and rhetorical tools is increasingly important and lawyers who understand these techniques are much more powerful as advocates. 
separating the subject matter knowledge a law school graduate is expected to know from the seat-time measured in the first year, credits can be reallocated to maximizing the learning of core competencies in the first year that will better enable students to cover more substantive knowledge in the remainder of law school.

This will be essential for any reform. Assuming that three years is the maximum limit for any competitive J.D. program (and five semesters could become the preferred modality), the time spent must be allocated more efficiently to cover the skills not presently being taught. Particular subjects covered within the first-year curriculum may be better taught later or be identified for competency testing. ${ }^{224}$ Students would take tests to assure their law school that they have garnered the appropriate subject matter competency the school demands, whether learned through classroom instruction, research projects, or self-mediated learning exercises. ${ }^{225}$

Law schools vary considerably on the additional courses required. Nonetheless, there is great convergence on courses such as Constitutional Law, Evidence, Business Associations, Federal Income Tax, Criminal Procedure, Trusts and Estates, and Uniform Commercial Code. ${ }^{226}$ Again, these closely match the subjects reflected on the Multistate Essay Examination which tests Business Associations, Conflict of Laws, Family Law, Federal Civil Procedure, Trusts and Estates, and Uniform Commercial Code in addition to the subjects on the MBE. ${ }^{227}$ Whether required or not, the role of these courses on a majority of bar examinations drive a large segment of law students to take these courses. Given the criticism of teaching legal analysis in the first year, it is highly doubtful that careful consideration is given by most faculty to this skill in the upperdivision bar tested courses.

A corollary to this change requires an emphasis on formative evaluations. ${ }^{228}$ Faculty provide formative assessments to provide the

${ }^{224}$ See Michael Hunter Schwartz, Teaching Law by Design: How Learning Theory and Instructional Design Can Inform and Reform Law Teaching, 38 SAN DIEGO L. REV. 347, 365 (2001) [hereinafter Schwartz, Teaching Law by Design]. Professor Schwartz accurately identifies much of the current law school methodology as self-taught learning. As he recognizes, self-teaching "encourages critical thinking skills, by giving leamers incentives to think critically and logically about court opinions and the students' own views." Id. Professor Schwartz, however, calls for courses to be taught more effectively using instructional design theory to direct and improve a student's learning. That leaves a gap in the legal education for self-directed leaming that can be provided through other modules and courses. Id.

${ }^{225}$ See infra note 241 and accompanying text. (2004).

${ }^{226}$ A SURVEY OF LAW SCHOOL CURRICULA, A.B.A. SEC. OF LEGAL ADMISSION TO THE BaR 16

${ }^{227}$ Multistate Tests, supra note 218 (listing MEE subjects). The MEE is now used in twentyseven jurisdictions, with the state of Washington state scheduled to be the twenty-eighth as of July 2013. 2011 Bar Examination and Admission Statistics, NAT'L CONF. BAR EXAM'R, http://www.ncbex.org/assets/media_files/Statistics/2011 Statistics.pdf (last visited Feb. 24, 2013).

${ }^{228}$ Greg Sergienko, New Modes of Assessment, 38 SAN DiEGO L. REV. 463, 467 (2001). 
student feedback, aid learning, and shape the student's progress toward the desired outcome. ${ }^{229}$ When the goals of the learning are only implicit, the faculty member is poorly placed to provide meaningful formative evaluation and effective feedback. And even if the faculty member provides such feedback, the student may discount or ignore it since the student is focused on content coverage rather than the hidden agenda of the instructor.

At a minimum, therefore, law schools should begin paying attention to the learning outcomes listed in the MacCrate Report statement of skills and values and assigning responsibility for students' learning outcomes in these courses. ${ }^{230}$ Increasingly, this will become an accreditation requirement by the $\mathrm{ABA}^{231}$ As such, the time spent on these core subjects cannot be immune from the learning outcome goals of the Carnegie Report and MacCrate Report statements of skills and values.

Where the core curriculum is most successful at translating the MacCrate Report and Carnegie Report to practice is in the various mandatory legal research and writing courses provided both to first-year and upper-division students. ${ }^{232}$ While there is more diversity around the pedagogy in these courses than their subject matter counterparts, relatively few are tasked with integrating substantive knowledge. ${ }^{233}$ One fairly

${ }^{229}$ Rogelio A. Lasso, Is Our Students Learning? Using Assessments to Measure and Improve Law School Learning and Performance, 15 BARRY L. REV. 73, 78 (2010). See generally S. GREGORY MUNRO, OUTCOMES ASSESSMENT FOR LAW SCHOOLS (2000) (providing practical guidance on the development and application of an assessment program for law schools).

${ }^{230}$ B. Glesner Fines, The Impact of Expectations on Teaching and Learning, 38 Gonz. L. REV. 89, 122 (2003); MACCRATE REPORT, supra note 200, at 140.

231 Donald J. Polden, Statement of Principles of Accreditation and Fundamental Goals of $a$ Sound Program of Legal Education, 40 SYLLABUS: A.B.A. SEC. OF LEGAL EDUC. \& ADMISSIONS TO THE BAR 1, 13 (2009), available at http://digitalcommons.law.scu.edu/facpubs/517/; see also STEVE BAHLS, AM. Bar ASS'N, Key ISSUES CONSIDERED By THE STUDENT LEARNING OUTCOMES SUBCOMMITTEE 1 (2009), available at http://apps.americanbar.org/legaled/committees/Standards\%20Review\%20docume nts/AALS $\% 202010 \% 20$ Meeting\%20Materials/Learning\%20Outcomes $\% 20$ Discussion $\% 20$ of $\% 20$ Key $\% 20$ Issues\%20January\%202010.doc (indicating that "[a]ccreditation review in the law must move law schools toward articulation and assessment of student leaming goals and achievement levels"); Cassandra L. Hill, Peer Editing: A Comprehensive Pedagogical Approach to Maximize Assessment Opportunities, Integrate Collaborative Learning, and Achieve Desired Outcomes, 11 NEV. L.J. 667, 667-68 (2011) (noting the same).

${ }^{232}$ See, e.g., Sarah Valentine, Legal Research as a Fundamental Skill: A Lifeboat for Students and Law Schools, 39 U. BALT. L. REV. 173, 178 (2010) ("Legal research is a legal skill that teaches basic legal knowledge necessary for successful completion of law school. It also requires issue-spotting, legal analysis, and the application of law to facts. When taught as a legal skill, legal research reinforces and supports the learning of doctrine and analysis. Legal research is also a fundamental lawyering skill necessary for the practice of law. It is the lawyering skill that provides the knowledge necessary for other lawyering skills such as interviewing, writing, negotiation, and counseling." (citations omitted)).

${ }^{233}$ Some law schools have integrated legal writing into the teaching of substantive law courses. See Allen Boyer, Legal Writing Programs Reviewed: Merits, Flaws, Costs, and Essentials, 62 CHI.KENT L. REV. 23, 29-30 (1985) (discussing the legal writing program at the University of Iowa, which 
radical approach to the first-year curriculum suggests having the majority of credits assigned to the legal research and writing components, with a small complementary number of credits earned as students demonstrate competence in particular subject matters along the way. ${ }^{234}$

In the upper-division courses, the greatest expansion towards learning outcomes has emerged in clinical education and field placement programs. ${ }^{235}$ Done well, these programs provide the maximum impact in achieving the skills and values of the profession while addressing the learning outcomes of the student. Credit hours should be expanded to allow students to maximize participation in such learning environments. Describing one such model clinical program, Professor Ann Marie Cavazos explains the pedagogical goals of such a clinic or field placement.

The Model Clinic program assessments are both formative and summative. The assessments are formative in that the Clinic structure is set up to facilitate the student's learning, and at the same time, to provide extensive feedback to the clinic supervisors, staff attorney, extern supervisors, and the student-attorneys on a continuous basis. They are summative in that the student-attorney receives mid-oral evaluation and assessment testing, which evaluates the student-attorney's knowledge and abilities. It also provides the Model Clinic with valuable information on how well the student-attorney is developing, learning, and utilizing the training provided. ${ }^{236}$

At the same time, however, part-time students with full-time professional commitments may be unable to commit to a twelve-credit semester in such a program or even a three-credit experience offered at night or on weekends. Each school should look to see which of these learning outcomes can be delivered outside of the credit hour. Students doing paid work in law firms could still benefit from reflective learning exercises and other formative assessments. While care would need to be taken to ensure attorney/client fidelity and avoid any conflicts caused by the law school, students could certainly engage in reflective learning

incorporates three major research projects into the substantive courses taught by the same doctrinal professor).

${ }^{234}$ Regardless of the merits of this particular model, few existing law faculty members would likely be interested in undertaking such a curriculum, highlighting the problem of entrenched staffing issues with vetoing disruptive innovation.

${ }^{235}$ See CARNEGIE REPORT, supra note 200, at 12 (law schools are "uniting, in a single educational framework, the two sides of legal knowledge ... formal knowledge and . . . the experience of practice"); see also Rebecca Sandefur \& Jeffrey Selbin, The Clinic Effect, 16 CLINICAL L. REv. 57, 5859 (2009) (discussing the rise of clinical education programs in most law schools).

${ }^{236}$ Ann Marie Cavazos, The Journey Toward Excellence in Clinical Legal Education: Developing, Utilizing and Evaluating Methodologies for Determining and Assessing the Effectiveness of Student Learning Outcomes, 40 Sw. L. REV. 1, 10 (2010) (citations omitted). 
regarding their experience.

Northeastern Law School provides an excellent example of pedagogical use of un-credited field placements. Its cooperative legal education model has been offered since $1968,{ }^{237}$ rotating quarters between real experience and legal education. ${ }^{238}$ The reflective learning and use of the experience in the classroom need not only come from a for-credit clinical experience or a field placement concurrently supervised by a fulltime faculty member. Learning can occur at all times and in all situations.

Similarly, students who may be unable to commit to a course for aspects of their experiential learning could nonetheless manage a number of community service hours as part of a school's Universal Service Requirement. $^{239}$ A law school can design criteria for its Universal Service Requirement that emphasizes law school skills, tracks the skills and values of the program and does not preclude categories of students from attendance. $^{240}$

Another approach is to provide the learning outcomes in a classroom setting, such as the General Practice Skills course designed for Phoenix Law School. ${ }^{241}$

By the end of the course students will have: (1) practiced many of the skills they will use in the practice of law; (2) experienced how lawyers solve legal problems, interviewed and counseled clients, investigated facts, negotiated settlements, handled appearances before a court, drafted legal

${ }^{237}$ Cooperative Legal Education Program, NORTHEASTERN UNIV. SCH. OF LAW, http://www.northeastern.edu/law/co-op/index.html (last visited Jan. 29, 2013) ("We integrate four quarters of full-time employment into our curriculum. You'll do real work in real legal settings-at law firms, with judges, and in public interest law settings, including government and service organizations.").

${ }^{238}$ Id. ("After you complete your first year of academic study, you'll begin alternating quarters as a full-time student with quarters as a full-time legal professional. On co-op, you'll put classroom theories, and theories about yourself, to the test. You and your peers will bring those experiences and diverse perspectives back to the classroom for enriching discussions and preparation for your next assignment.").

${ }^{239}$ To the extent pro bono must be voluntary, the phrase "universal service" does not. Even "compulsory pro bono" works since the choice to become a law student was the voluntary decision--a decision that comes with certain commitments depending on the law school attended. See Pro Bono Publico, A.B.A., http://www.americanbar.org/groups/legal_education/resources/pro_bono.html (last visited Jan. 29, 2013) (discussing the importance of considering pro-bono opportunities for prospective students in choosing a law school).

${ }^{240}$ For example, building houses for Habitat for Humanity emphasizes skills other than those of traditional lawyering, so a pedagogically sound universal service requirement would likely focus most hours on law-related services. See Volunteer Opportunities--United States, HaBITAT fOR HUMANITY, http://www.habitat.org/print/us_volunteer_program (last visited Feb. 26, 2013) (discussing volunteer activities including "assist[ing] reconstruction crews with maintenance work, help[ing] with drafting assignments, and support[ing] various program operations").

${ }^{241}$ Stephen Gerst \& Gerald Hess, Professional Skills and Values in Legal Education: The GPS Model, 43 VAL. U. L. REV. 513, 527-28 (2009). 
documents, prepared cases for dispute resolution, and advocated on behalf of clients; (3) become knowledgeable and sensitive to the professional values deemed important by the bench and bar; (4) demonstrated a commitment to high ethical standards and professionalism in dealing with clients, opposing counsel, courts, and the community; and (5) acquired a realistic basis to make decisions about different areas of the law as a career. ${ }^{242}$

Such a class could complement a field placement or clinical program to better prepare the student and enable the student to get that much more out of the course. It could also precede a paid (or unpaid) non-credit internship or pro bono experience to make that experience also part of the broader learning path that the student has undertaken.

The key to providing these courses and skills is that law schools must teach them more efficiently so that there is time to prepare students for everything else that must occur within the constraints of the J.D. degree.

\section{Adding Meaning to MacCrate: Which Skills and Values Are Missing}

The previous discussion of the MacCrate Report statement of skills and values merely highlights a discussion that has been ongoing throughout the legal academy. ${ }^{243}$ None of these changes, though critical to improve legal education, address the related changes to the practice of law. Worse, to the extent we offer simulation courses and clinical programs that ignore the changes to the professional environment, these courses will interfere with the student's preparation into practice.

\section{Match the Curriculum to the Practice}

As noted earlier, $64 \%$ of attorneys have a corporate practice ${ }^{244}$ and an additional $10 \%$ work as inside counsel, ${ }^{245}$ so nearly three-quarters of all practicing graduates are part of a corporate practice. ${ }^{246}$ This does not dictate that litigation be removed from the curriculum, but it strongly suggests that the curriculum should be more carefully balanced to reflect the actual practice environment in which most graduates will work.

For all corporate attorneys and most litigators who practice on behalf of corporations, the fundamental understanding of business should be provided. In practice, courses developed out of the MBA curriculum

${ }^{242} I d$.

${ }^{243}$ Outcome Measures Report, supra note 207, at 6-11.

${ }^{244}$ Heinz et al., supra note 17 , at 4.

${ }^{245}$ Hackett, supra note 19 , at 610 .

246 This does not mean, of course, that many of these attorneys are not litigators for corporate clients. Nonetheless, even litigators should understand the objectives of their clients both in the immediate litigation and in their broader strategy. 
would reflect the MacCrate Report statement of skills and values for "organization and management of legal work,"247 as well as potentially for "factual investigation." "248 While there exists a wide range of MBA programs, there is a core curriculum that would be quite helpful for most lawyers. As separate classes, the following would be important for at least a working knowledge:

The Strategic and Tactical MBA

- Management Strategy

- Macroeconomics

The MBA Toolbox

- Quantitative Analysis (Statistics, Decision Analysis and Modeling)

- Managerial Economics

The Functional MBA

- Operations Management

- Marketing

- Financial Accounting

- Managerial Accounting

- Corporate Finance

- Information Technology

The Organizational and Leadership MBA

- Organizational Behavior and Leadership

- Human Resources Management ${ }^{249}$.

${ }^{247}$ MACCRATE REPORT, supra note 200, at 140.

${ }^{248} I d$. at 138.

${ }^{249}$ Peter Navaro, Ed., What THE Best MBAs KNow 7 (2005) (discussing the MBA Core Curriculum at the Top 50 U.S. Business Schools); see also ROBERT F. BRUNER ET AL., THE PORTABLE MBA, at vii-viii (3d ed. 1997). The Portable MBA, for example, suggests the following topics constitute the minimum coverage necessary to understand business:

1. "What is Business?" including "Understanding Business Ecosystems," "The Intelligent Enterprise," and "The Internet."

2. "The Future" including "Elements of Developing Scenarios" and "Macrotrends."

3. "Managing People" including "Human Resources Management."

4. "Business Ethics" which, since they are not the same as legal ethics, is essential for a business lawyer to understand where the differing lines will be drawn.

5. "Economics" including both "Microeconomics" and "Macroeconomics" which is essential for the lawyer in understanding client needs and understanding the dynamics of the lawyer's own firm.

6. "Marketing Management: Leveraging Customer Value" which again applies both to any client and to the lawyer's own firm.

7. "Operations Management."

Id. 
A lawyer working for corporate clients who has had no experience understanding the needs of the industry or the workings of the corporate culture is highly disadvantaged over the student who has been exposed to both. Moreover, since everyone other than the occasional contract attorney is engaged in working for or managing a business enterprise, perhaps the curriculum should require knowledge of how to run such an organization. ${ }^{250}$ At a minimum, the courses of Human Resources Management and Organizational Behavior and Leadership should be highly encouraged for all students. ${ }^{251}$

The MBA curriculum for law school need not be as in depth as a full MBA, and as discussed below, the delivery can include both class time and other measures of competency, but a significant amount of the upper division curriculum should prepare law students for the business world into which most will graduate. At a minimum, the curriculum should address the Best Practices competency to "[d]emonstrate an appreciation of the commercial environment of legal practice, including the market for legal services.",252

The MBA coursework on quantitative analysis provides one set of tools for factual analysis and empirical research, but factual analysis needs to be taught much more explicitly. Law students may learn the rules of evidence to help them understand what facts can be submitted to court, but relatively few courses and few students are exposed to actual factual gathering training. This is an area where law students and journalism students could learn together. Both fields struggle to develop techniques and ethics to address verifiable factual investigation techniques. The interdisciplinary training would likely benefit both student populations.

Similarly, the MacCrate skill of communication is rarely taught directly. Law school courses in Rhetoric can provide a very formal training. But in this age of ubiquitous digital media, understanding communication - both how to communicate more effectively and how to become more discriminating in one's legal and factual research-requires additional coursework that can come from law schools, journalism departments, communication departments or other sources, depending on the organization of the university.

An updated scan of the economy might also dictate certain other course recommendations. For example, some studies suggest that as much

${ }^{250}$ See Shultz \& Zedeck, supra note 208, at 644 (listing business-related skills among those that correlate with professional success in practice).

251 The proposals included do not generally support mandatory courses beyond that which is presently taught in the first year, along with professional responsibility. What is good for most students may not be good for all. Pre-set schedules that allow for student changes will likely achieve the educational goal for most students without the unintended consequences of large-scale requirements for mandatory course schedules.

${ }^{252}$ BEST PRACTICES RePORT, supra note 200, at 53-54. 
as $80 \%$ of the value of publicly traded companies resides in their intangibles rather than in their tangible assets. ${ }^{253}$ "[T] raditional accounting measures are inadequate for determining real corporate value in the knowledge-based economy. Valuing intellectual capital is important to enabling companies to realize true value." ${ }^{\text {"54 }}$ Courses that explore intellectual property and valuation may be very important to the next generation of law students. Commercial law (or electronic commerce) practice has seen a similar transformation in form and content. ${ }^{255}$ International law, including human rights and international trade, affect a growing part of the U.S. economy. Schools should be able to adequately recommend appropriate courses for various career paths and make room in their curricula for electives sufficient to enable a student to specialize. Although the subjects in the first year must remain, the credit hours allocated should reflect the changes in practice and the need to expose students to a wider array of topics.

Co-curricular activities suffer from a reality gap as well. While law schools regularly bring judges before their student bodies to help bridge the gap between legal education and the practice, many graduates will never practice before a judge. Similarly, were the curriculum to reflect practice demands then standard legal writing programs would not start with an appellate brief, a document that will never be drafted by the vast majority of students in practice. ${ }^{256}$ Both in particular courses and in the tools used to teach more general courses, the curriculum should reflect what the modern practice of law entails, rather than an historical notion of lawyer as solo-litigator.

\section{Match the Curriculum to the New Business of Law}

For law students to survive in the globalized, technologically mediated environment in which they will find themselves, they need to be able to operate effectively using the tools available to them. The Best Practices

${ }^{253}$ See Chun-Yao Tseng \& Yeong-Jia James Goo, Intellectual Capital and Corporate Value in an Emerging Economy: Empirical Study of Taiwanese Manufacturers, 35 RES. \& DEV. MGMT. 187, 188 (2005) ("F]urthermore, the other study also indicates that $80 \%$ of the value of a company is intangible.").

${ }^{254} \mathrm{Id}$.

${ }^{255}$ Amelia H. Boss, The Evolution of Commercial Law Norms: Lessons to Be Learned from Electronic Commerce, 34 BROOK. J. INT'L L. 673, 675 (2009) ("The speed with which electronic commerce has developed and spread throughout the world has placed a premium on the need to develop governing norms definitively and just as swiftly. As a result, what took generations to occur in areas such as sales or secured transactions has occurred in a matter of decades with electronic commerce.").

${ }^{256}$ Law schools may use legal briefs because they relate to the appellate cases written by judges. Little of the drafting, however, goes to the rhetorical design of the brief to anticipate the published opinion of the court, nor would such pedagogy be relevant to most students. What relevance likely exists is to the clerkship experience of most law faculty. 
Report reflected this transition by adopting the competencies based upon those proposed by the Law Society of England and Wales. ${ }^{257}$ Since the legal practice in England does not bar ownership by non-lawyers, the accounting firms have consolidated Big Law to create some of the largest service organizations and as a result, ${ }^{258}$ lawyers must understand the business of law and the technology affecting legal practice. ${ }^{259}$

At a minimum, this means every law school should provide an up-todate law practice management curriculum available to every student, one that teaches a lawyer how to meet all the duties of professional responsibility (including the newly proposed duty to stay current with technology and protect the digital information held on behalf of a client). ${ }^{260}$ The Best Practices study captures this competency as expecting a new lawyer to "[e]ffectively use current technologies and strategies to store, retrieve and analyze information and to undertake factual and legal research."261 Students who graduate from forward-thinking legal technology courses have the potential to leapfrog over more senior attorneys who are unwilling to keep up with these tools and the changing expectations of their clients.

Similarly, just as "human resources" and "managing people" is explicitly stated in the Portable $\mathrm{MBA}^{262}$ the law practice curriculum should provide for explicit learning outcomes to manage lawyer collaboration, work environment issues, and issues relating to the operations, financings, and organizational health of the firm. Legal education has been universally critical of the expansion of Big $\mathrm{Law}^{263}$ but few, if any, courses are geared to teaching the better way to operate a legal enterprise. Such a curriculum would deal with teaching how to manage efficiently; different types of employment and independent contractor structures; labor and employment law issues from a very pragmatic standpoint; and marketing and promotion. Another component would focus on training the lawyer to institute methods of scale into one's

${ }^{257}$ BEST PRACTICES REPORT, supra note 200, at 54.

${ }^{258}$ See, e.g., Chris Johnson, Continental Breakfast: The Dark Art of Law Firm Valuation, AMLAW DAILY (Mar. 23, 2012, 6:00 AM), http://amlawdaily.typepad.com/amlawdaily/2012/03/continentalbrea kfastlawfirmvaluation.html (discussing recent legislation that allows U.K. law firms to extend ownership to non-lawyers, resulting in extremely large and valuable law firms).

${ }^{259}$ BEST PRACTICES REPORT, supra note 200, at 53-54.

260 See MACCRATE REPORT, supra note 200, at 140 (stating that in order to be effective practitioners, attorneys should be familiar with skills for efficient management of work, including developing systems to make sure that time and resources are allocated efficiently, developing systems to make sure that work is completed on time, being able to work effectively with other people (including fellow attorneys and support staff such as paralegals), and being able to handle the administrative work of running a law office in general).

${ }^{261}$ BEST PRACTICES REPORT, supra note 200, at 54.

${ }^{262}$ ROBERT BRUNER ET AL., THE PORTABLE MBA 31, 42 (3d ed. 1998).

${ }^{263} \mathrm{Id}$. at $26,215$. 
practice.

These skills and practices could certainly be taught in a law firm simulation course or in conjunction with the training associated with clinical and field placement education. The goal is not more coursework, but rather a more direct relationship between what a student does and what a lawyer does. Law schools should begin experimenting with simulations using virtual law firms to engage students in the technology and improve students' self-directed learning. Like every other skill, it is better for a student to breach his or her duties of confidentiality or data security with a hypothetical client in a low stakes setting than to face the issue for the first time with a real client and with potentially devastating high-stakes negative outcomes.

Against this backdrop, faculty should demand that the new modes of legal practice be considered within the context of the values of the profession. ${ }^{264}$ The provision of competent representation creates an interesting analysis in the context of self-help tools and unbundled legal services that students should explore while professional self-development may take on new dimensions in the context of the digital age. Striving to improve the profession should already be part of both general and specific law practice management curricula, but if the predictions about the restructuring of the legal field come true, the topic takes on new relevancy.

The value of striving to promote justice, fairness, and morality should be universal, regardless of technological change, but it needs to be given attention. Particularly in the age of globalization, the questions about the role of law and universal access to justice remain central to the profession and the ethos unique to law graduates.

Beyond the general courses for all students, some specialization should be available. A more sophisticated course which should be offered to students with some technological training from other colleges in the university could teach students how to systematize legal work. While all lawyers would benefit from some exposure to learning how to become more productive, specialty courses in legal systemization are necessary so that the purveyors of the self-help technology are not entirely self-taught.

Finally, law schools must recognize that much of the specialized work has moved out of the traditional practice of law into the various new fields requiring legal accountability as part of a broader statutory compliance regimen. As health compliance, data security and privacy compliance, and financial compliance grow, so will the need for compliance officers and

${ }^{254}$ Id. at 79; see also CARNEGIE REPORT, supra note 200, at 132-35 (rejecting the idea that students' sense of values are permanently established by the time they reach school and reporting that in cases where professional legal ethics were taught in smaller, more intensive seminars, students' moral judgment scores improved notably as compared to teaching ethics and values in the typical class format). 
attorneys trained in both the disciplines of law and those other sectors. The J.D. may serve as a sufficient post-graduate degree for such positions, but the law graduate also needs the substantive and technical knowledge of the industry into which they are moving. Law schools need to develop systems to embrace these more individualized courses of study in order to prepare their students for the future.

\section{Rethinking How to Deliver Legal Education}

One of the limitations on the development of legal education is the accreditation regime. ${ }^{265}$ This is nothing new. As Clarence Darrow noted,

$[t]$ he bar association of to-day lay down every conceivable condition; they require a longer preliminary study, and exact a college education and long courses in law schools, to keep new members out of the closed circle. The Lawyers' Union is about as anxious to encourage competition as the Plumbers' Union is, or the United States Steel Co., or the American Medical Association. ${ }^{266}$

But this limitation is also largely illusory. The Section of Legal Education and Admission ("Section") to the bar is largely comprised of law deans, faculty and lawyers so that any change that comes from within will be supported. Moreover, the Department of Education expects the Section to seek meaningful educational reform. The teaching of legal education is more diverse than often recognized. ${ }^{267}$

Clinical education and field placements represent strong steps forward in the delivery of learning outcomes that are tied to the goals of the practice. Darrow lamented the lack of such training in his education: "I had never had any experience in court work or in the preparation of cases.

${ }^{265}$ See Steven C. Bennett, When Will Law School Change?, 89 NEB. L. REV. 87, 104-05 (2010) (noting that law schools are "steeped in a culture of academic "competition and conformity and seem to resist change even beyond the norms of most educational institutions"); Jon M. Garon, Take Back the Night: Why an Association of Regional Law Schools Will Return Core Values to Legal Education and Provide an Alternative to Tiered Rankings, 38 U. TOL. L. REV. 517, 517 (2007) (arguing that because of baseline accreditation requirements placing pressure on law schools to conform, the ability to reach a "broadly diverse group of law students" has been restricted, thus limiting the quality of legal services available to the public); George B. Shepherd \& William G. Shepherd, Scholarly Restraints? ABA Accreditation and Legal Education, 19 CARDOZo L. REV. 2091, 2096 (1998) (arguing that the ABA accreditation system has essentially become a union for law school faculty, supported by law schools because the system limits competition and many law schools effectively operate as partnerships for professors, who obviously support an organization that will increase the benefits they receive).

${ }^{266}$ Clarence DaRRow, THE STORY OF MY LiFE 29 (1932).

${ }^{267}$ See Rapoport, Changing the Modal Law School, supra note 204 (noting the more innovative aspects of some schools, such as Northeastem University School of Law's rotation of semesters focusing on traditional academics and internship semesters and Northwestem University Law School's using student teams to complete coursework and attempts to attract students with at least two years of work experience before beginning law school). 
I then knew, and have ever since been aware, that I needed specific training which I could not get."268

Clinical education and field placements often deal with the student's personality traits, yet much more needs to be done to identify the traits successful for lawyers. ${ }^{269}$ Teaching materials and explicit learning outcomes should be developed to reinforce those traits, educate students to develop those traits, and provide formative assessment to encourage effective behaviors of students. ${ }^{270}$ "Effective lawyering, like performance in many careers, relies on varied dimensions of human intelligence.,271 When a faculty member or supervisor observes a student interacting with a client, these observations are often shared. This training can be extended to simulation courses throughout law school. The result of a curriculum based on the skills, traits and values described above maps quite congruently to the twenty-six attributes of success identified by Marjorie M. Shultz and Sheldon Zedeck in their seminal 2008 study on successful traits for practicing lawyers. ${ }^{272}$

To achieve the skills, attributes, and values that the modern legal education seeks, the next important step is to reduce the emphasis on the classroom. If the accreditation process has truly shifted to focus on learning outcomes, then the Section of Legal Education should be willing to measure the effectiveness of a law school program by the integrity of its learning outcomes and the success of students achieving those outcomes rather than the minutes of instruction provided. "Students who think critically about what and how they are learning, and who take responsibility for the quality of their own education, may enjoy greater satisfaction because they have more control over their experience.'

${ }^{268}$ DARROW, supra note 266, at 31.

269 Shultz \& Zedeck, supra note 208, at 625 (discussing how "traditionally labeled 'noncognitive' predictors like personality, interpersonal skills, and practical judgment . . . have been identified and found to be valid predictors of performance").

${ }^{270} \mathrm{Id}$. at 630 . Such additional trait-based skills include "Able to See the World Through the Eyes of Others . . Passion and Engagement . . Diligence . . Integrity/Honesty . . . Stress Management . . . [and] Self-Development." Identified professional skills include "Strategic Planning ... Organizing and Managing One's Own Work ... Organizing and Managing Others (Staff/Colleagues) ... Networking and Business Development . . . [and] Providing Advice \& Counsel \& Building Relationships with Clients." Id.

${ }^{271} I d$. at 625 .

${ }^{272} I d$.

${ }^{273}$ Jane H. Aiken et al., The Learning Contract in Legal Education, 44 MD. L. REV. 1047, 1049 (1985); see also Gerald F. Hess, Collaborative Course Design: Not My Course, Not Their Course, but Our Course, 47 WASHBURN L.J. 367, 379 (2008) (comparing a course syllabus to a "leaming contract" and arguing that even though negotiating individual leaming contracts with each student in every class may not be practical, it is usually still possible for students to be involved to some degree in syllabus construction). See generally Michael Hunter Schwartz, Teaching Law Students to Be Self-Regulated Learners, 2003 MICH. ST. L. REV. 447, 449-50 (2003) [hereinafter Schwartz, Self-Regulated Learners] (providing an overview of some popular self-regulated learning theories). 
Professor Hess provides a roadmap for effective syllabi design that applies equally well to self-directed learning modules:

Course design decisions include five components: (1) Goals-articulating the knowledge, skills, and values students should learn in the course; (2) Materials--finding appropriate texts and electronic resources; (3) Assignmentsidentifying readings and projects to be completed in and out of class; (4) Methods-choosing teaching and learning approaches; and (5) Evaluation-determining the grading scheme, including exams, quizzes, papers, and participation. Those decisions should be detailed in the syllabus so that teachers and students can rely on them throughout the course.

Additionally, the syllabus should serve as a contract between teacher and students, which delineates their respective responsibilities and guides their behavior during the course. All of the course design decisions described above are part of the contract. ${ }^{274}$

The six steps outlined provide a summary of how to design a teaching module that carefully sets out the goals for the student, identifies the appropriate materials from which to learn, the particular assignments to be completed, the review and feedback process for each step in that learning, the summative evaluation that will result in a grade, and the commitments of the student and faculty member to the path. ${ }^{275}$ Faculty members may be highly involved in such a process, steering strong students to more challenging work, and assisting weaker students to identify the source of their weakness (substantive knowledge, writing, analytical thinking, time management, etc.) and providing formative feedback to keep the student on task. ${ }^{276}$ Such modules need not computerize the faculty member's role (though it can systematize some aspects of it). But it must be tied to

${ }^{274}$ Hess, supra note 273, at 373 (citations omitted).

275 See Schwartz, Teaching Law by Design, supra note 224, at 366 ("[l]nstruction is 'the deliberate arrangement of learning conditions to promote the attainment of some intended goal.' What is missing from this definition is particularly significant; instruction does not necessarily equate with classroom teaching." (quoting MARCY PERKINS DRISCOLL, PSYCHOLOGY OF LEARNING FOR INSTRUCTION 332 (1994))); Schwartz, Self-Regulated Learners, supra note 273, at 470 (stating that "a crucial quality for a lawyer is autonomous learning, the ability to learn what needs to be learned to cope with a novel situation" (quoting Jay Feinman \& Marc Feldman, Pedagogy and Politics, 73 GEO. L.J. $875,894(1985))$ ).

276 See Schwartz, Self-Regulated Learners, supra note 273, at 454 ("Thus, in courses in which teachers emphasize self-regulated learning, 'the teacher's primary role in promoting self-regulated learning is to help students assume responsibility for their own learning progress. . . . The teachers' goal is to work themselves out of the job of managing their students' learning." (quoting BARRY J.

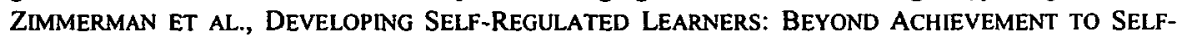
EFFICACY 17-18 (1996))). 
competency rather than seat time.

Dean Dennis Honabach has raised this question quite explicitly. "Consider the typical law school course. It reflects a number of assumptions about 'average' performance. First, the concept of a course itself is based on a notion of average - in this instance on the notion of the chunk of 'learning' we can expect of the 'average' law student in our classes during a fifteen-week semester." ${ }^{277}$ He notes that other industries have done much to disaggregate processes to improve efficiency and turns the question to legal education. ${ }^{278}$ Dean Honabach's model focuses on the use of computer-aided instruction within a classroom but it is equally appropriate for students in outcome based settings. ${ }^{279}$

A variation on the model incorporates the influence of the practicing bar. As part of a student's work product, the student uploads samples of the various contracts, memoranda, briefs, and research papers to a digital portfolio service. This work product is created by the student both inside various classes and outside the classroom. ${ }^{280}$ In addition to the grading provided by each faculty member who assigned a particular project, the law school could have a distribution requirement requiring each student to upload a specified number of projects representing various categories of work product to the personal digital portfolio.

Two scenarios are possible. In the first, such work product would be made available to the public. Any FERPA or privacy restrictions would be waived by the student as a condition of enrollment. In the second scenario, the documents would be publicly accessible, but only upon approval by the student. The beauty is that it would not matter. Employers aware of the portfolio would be likely to seek access as a condition of interviewing; strong students would encourage it. Under such a portfolio requirement, student-learning outcomes become quite explicit and the importance of

${ }^{277}$ Dennis R. Honabach, Precision Teaching in Law School: An Essay in Support of StudentCentered Teaching and Assessment, 34 U. TOL. L. REV. 95, 95-96 (2002).

${ }^{278} \mathrm{Id}$. (noting that farmers, for example, have adopted "precision farming" techniques using GPS and computer yield monitors to adapt their farming methods to specific sites more accurately, which has increased their efficiency and total output).

${ }^{279}$ Id. at 102.

${ }^{280}$ The portfolio approach has been recognized elsewhere. See BEST PRACTICES REPORT, supra note 200, at 261-63 (encouraging portfolios as tool for student self-reflection); CARNEGIE REPORT, supra note 200 , at 174 (noting that although almost all law schools currently maintain some elements of student portfolios by keeping records of at least students' first-year essays and their grades for all three years, this system could be vastly improved upon by adding more detailed information such as evaluations by supervisors, research papers, briefs, and so on); Anthony Niedwiecki, Teaching for Lifelong Learning: Improving the Metacognitive Skills of Law Students Through More Effective Formative Assessment Techniques, 40 CAP. U. L. REV. 149, 185 ("A portfolio allows the students to reflect on their leaming over the course of the semester, the main purpose of self-assessment tools."); Garvey \& Zinkin supra note 203, at 121 (noting that repeated review of the portfolio from multiple sources integrates the skills learned in law school, rather than keeping them as separate subjects taught in separate classes). 
good drafting is suddenly driven by the market. Schools may grapple with questions such as whether students should be able to update their works as they progress throughout law school. Assuming the work is that of the student ${ }^{281}$ such updating will result in the student spending more time on tasks and building the skills and knowledge law school hopes the student achieves. Permission to update is another pedagogical victory for the institution.

With the stress on new courses, faculty may find it difficult to attract sufficient students to run their favorite seminars or specialty courses related to their scholarship. As many schools have begun to demonstrate, the technology for distance education-either through classroom to classroom live technology, online courses, or some hybrid - can provide students with access to faculty members across the globe. ${ }^{282}$ Law schools should engage in development of an open consortium so that smaller specialty courses can continue to be made available to students (and be available to be taught by faculty). ${ }^{283}$

In addition to moving away from seat time to a competency-based model, legal education has to begin to value other educators. Other than the need to increase law school revenue, there is little reason for many of the accreditation standards that prohibit law students from transferring credits from other graduate and professional education programs. To demand that the credits must only come from legal education is little more than prejudice and self-centeredness. Either we don't believe that the MBA, PhD and MD programs live up to our pedagogical demands, or we are insecure and fearful that once students can seek coursework elsewhere,

${ }^{281}$ An assumption that can be managed through Honor Code enforcements, secure web portals, and other similar techniques, if necessary.

${ }^{282}$ See, e.g., BLACKBOARD, http://www.blackboard.com/ (last visited Feb. 23, 2013) (providing a course content platform); ELECTA LIVE, http://www.e-lecta.com/ (last visited Feb. 23, 2013) (providing a virtual classroom software for online teaching); MOODLE, https://moodle.org/ (last visited Feb. 23, 2013) (providing an open source course content platform); WrIQ, www.wiziq.com/ (last visited Feb. 23, 2013) (same).

${ }^{283}$ Such a consortium could be coordinated by CALl, the ABA, AALS or a new arrangement. It must provide equal access to all accredited law schools to avoid charges of anti-competitive behavior. See, e.g., Harry First, Competition in the Legal Industry (II): An Antitrust Analysis, 54 N.Y.U. L. REV. $1049,1072-73$ (1979) (discussing how, although it is time-consuming and expensive for law schools to gain ABA and/or AALS accreditation, attempting to enter the legal education industry without those credentials is extremely risky); Andrew P. Morriss, The Market for Legal Education and Freedom of Association: Why the "Solomon Amendment" Is Constitutional and Law Schools Are Not Expressive Associations, 14 WM. \& MARY BILL RTS. J. 415, 418-20 (2005) (arguing that the ABA and AALS have worked together to promote a certain model of legal education and exclude other models from becoming prevalent in schools); Susan Hayes Stephan, Blowing the Whistle on Justice as Sport: 100 Years of Playing a Non-Zero Sum Game, 30 HAMLINE L. REV. 587, 593-95 (2007) (arguing that from the beginning of law school, future lawyers are encouraged to engage in competitive behavior in order to put the other party at as much of a disadvantage as possible. Stephan claims that this leads to a legal system with unnecessarily high levels of inefficiency and expense). 
they will flee to the four corners of campus, resulting in a loss of revenue and face.

Once legal education moves to a competency model, students should be free to learn additional topics elsewhere. There should be a core competency that every student must complete and a series of supplemental learning outcomes that can be interchanged and augmented so that every student is prepared to become the type of lawyer that person aspires to be.

How does this all add up? This could certainly be delivered as a $4+3+3$ program in which a student completes four years of undergraduate education, three years of law school, and three years of law practice. Unfortunately, that is unlikely to satisfy student expectations or justify the opportunity cost for the program's graduates. Instead of a $4+3+3$ model, law schools must continue to operate within the regime that caps full-time education at $4+3$.

To address some of the potential deficiencies in the four years of undergraduate education, law schools (individually, or together in conjunction with CALI) should develop some law school preparedness competencies. These self-directed online modules would require that students prepare themselves with a basic understanding of Civics, A.P.level English, and U.S. English grammar. Schools may use different admissions scores for such tests, but for domestic students in the bottom half of the admitted applicant pool, these skills are not uniform.

Similarly, for some students, particular courses in Economics, Financial or Managerial Accounting, or Corporate Finance or other recommended law/business courses could be satisfied by a placement test. The placement test would not reduce the number of credits a student needs for graduation, but it would allow her to take other subjects rather than repeat information learned in undergraduate education or in the field.

Beyond the placement tests, roughly half of the legal education would remain substantially similar to the course topics presently taught. The courses tested by the bar-Legal Research and Writing, and Professional Responsibility - take close to three semesters. The additional courses on Legal Logic, Rhetoric and Communications, and Law Office Management will hopefully be included in that half of the calculation, though these other core-MacCrate skills courses could take the majority of a fourth semester.

Of the remaining time, ideally one semester's worth of credit hours would be spent on live client experience through some combination of field placement and clinical education. The credits may be spread out over different semesters, but the net credit earned should be at least one-sixth of the educational experience. Finally the remaining one-to-two semesters of credits would be spent on the new courses demanded by the new modes of legal practice and the advanced specialty courses in the students preferred field of practice.

The schedule hopefully will be far more integrated than the foregoing 
suggests. The first of the Law Practice Management courses should be taught at the same time as Professional Responsibility and courses in increasing sophistication of skills and knowledge. Scheduling flexibility would come from more self-directed learning modules. Graduates may also be encouraged to continue taking these modules for free in the first few years of practice.

In addition, the notion of the semester may itself be reconsidered. Periods of shorter terms and longer terms may benefit the students substantially more than six 15 -week semesters. For example, many schools introduce legal education with a Legal Methods curriculum running from one to three weeks in length. This period can become part of "Fall Term A." Returning second year students use Fall Term A for courses in Professional Responsibility and Law Office Management, taught in boot camp fashion to prepare them for the rest of their legal education. With a focus on student outcomes and minimum competency, tremendous flexibility can be added to the program. The flexibility does not overcome the problem of limited time, but hopefully the flexibility and the increased range of subjects will overcome the perception of increasing irrelevance for the third year of law school.

\section{CONCLUSION}

Lawyers find clients through Facebook, they negotiate deals exclusively on their iPhones, and they submit court documents digitally. Increasingly they work from home and practice in virtual law firms. The shrinking demand by paying clients for expensive legal services will not rebound in a healthier economy; it has given way to efficient software and low-cost delivery of legal services. The legal profession is not going away, but it is being radically transformed. If Justice Holmes was correct in his observation that " $[t]$ he life of the law has not been logic: it has been experience, ${ }^{, 284}$ then the experience of the market should teach us that real change is at hand. Legal education should heed his advice and learn from the experience of the bar before it is too late; before our excess capacity and backward-looking curricula result in others putting our house in order for us.

For an increasing number of attorneys, these changes have begun to transform the practice of law into a technologically-savvy, highlynetworked, and increasingly systematized profession. Lawyers operating successfully in this milieu are harnessing the technology to improve their work-life balance, remain profitable, provide services demanded of their clients, and expand legal service to reach the broader public.

Legal education must follow their lead. Legal educators must find

\footnotetext{
${ }^{284}$ OLIVER WeNDELl HOLMES, THE COMMON LAW 1 (1881).
} 
room in the curriculum to teach the traits necessary for success, the technology that is used in forward-looking practices, the business skills essential to running a successful practice and interacting with a corporate client, and the live-client experience that makes real these lessons. To do so, law school must reduce emphasis on content, eliminate class time as a measure of learning, and teach intentionally rather than inductively. Graduates from programs embracing these changes will be the lawyers of tomorrow best prepared for success.

Society requires the best lawyers legal education can produce. Students deserve the best education law schools can provide. If not now, when? 